\title{
GEOLOGIC MAP \\ OF THE \\ MOUNT ADAMS QUADRANGLE, WASHINGTON
}

\author{
Compiled by
}

MICHAEL A. KOROSEC

\section{WASHINGTON DIVISION OF, GEOLOGY AND EARTH RESOURCES \\ OPEN FILE REPORT $87-5$}

1987 


\section{DISCLAIMER}

This report was prepared as an account of work sponsored by an agency of the United States Government. Neither the United States Government nor any agency Thereof, nor any of their employees, makes any warranty, express or implied, or assumes any legal liability or responsibility for the accuracy, completeness, or usefulness of any information, apparatus, product, or process disclosed, or represents that its use would not infringe privately owned rights. Reference herein to any specific commercial product, process, or service by trade name, trademark, manufacturer, or otherwise does not necessarily constitute or imply its endorsement, recommendation, or favoring by the United States Government or any agency thereof. The views and opinions of authors expressed herein do not necessarily state or reflect those of the United States Government or any agency thereof. 


\section{DISCLAIMER}

Portions of this document may be illegible in electronic image products. Images are produced from the best available original document. 


\section{INTRODUCTION}

This map is one of a series of 1:100,000-scale geologic maps compiled by staff geologists of the Division of Geology and Earth Resources. Other maps in the series are available or will be available for all 1:100,000-scale quadrangles within the southwest quadrant, that is, south of $47^{\circ} 5^{\prime}$ north latitude and west of $120^{\circ} 30^{\prime}$ west longitude, except for the Wenatchee and Snoqualmie Quadrangles which are available as U.S. Geological Maps. Other 1:100,000-scale maps in this series that have been released to date are:

Walsh, T. J., compiler, 1986, Geologic map of the west half of the Yakima quadrangle, Washington: Washington Division of Geology and Earth Resources Open File Report 86-4,9 p., 1 map sheet, scale 1:100,000.

Walsh, T. J., compiler, 1986, Geologic map of the west half of the Toppenish quadrangle, Washington: Washington Division of Geology and Earth Resources Open File Report 86-3,7 p., map sheet, scale 1:100,000.

Korosec, M. A., 1987 , Geologic map of the Hood River $1: 100,000$ quadrangle, Washington and Oregon: Washington Division of Geology and Earth Resources Open File Report 87-6,41 p., 1 map sheet, scale $1: 100,000$.

This text consists of unit descriptions, a table of age dates, a table of major element geochemistry, correlation diagram, source of mapping diagram, and a list of cited references. The conventions used in describing and classifying rocks are from the following sources: Igneous rocks are classified according to Travis (1955). If geochemical data are available, volcanic rocks are classified according to the current classification of the International Union of Geological Sciences (Zanettin, 1984). Most of the geologic units are informal, including all of the Quaternary volcanic rocks. The only formal units are Evans Creek Dr if $t$, Hayden Creek Drift, Eagle Creek Formation, Ohanapecosh Formation, and the formations and members of the Columbia River Basalt Group. 
Brent Barnett, supported by Contract DE-AC07-79ET27014 from the U.S. Department of Energy Geothermal Program, conducted reconnaissance mapping in the Green Mountain area during the summer of 1985. Kate Tysiak and Mark Menard provided field assistance to the author during the summer of 1984. Paul Hammond, Portland State University, provided unpublished mapping of the Indian Heaven area. Hammond's rock unit descriptions form the basis for most of the descriptions of the Quaternary volcanic units on this map. Don Swanson, U.S. Geological Survey, Vancouver, made available preliminary field data from his reconnaissance work in the northwest $1 / 4$ of the map area, and the Fairview Ridge 7.5' Quadrangle. James E. Smith, USGS, Menlo Park, shared an early draft of his Yakima $1^{\circ} \times 2^{\circ}$ geologic compilation map (scale 1:250,000) which was used to add a few lithologic details to the area along the east and south flanks of Mount Adams and the area north of Quartz Creek. Reviews by Hammond, Swanson, Smith, and Geoff Clayton (University of Washington) significantly improved this map, and the author greatly appreciates their efforts. 


\section{Geologic Unit Descriptions}

\section{Quaternary Sediments}

\section{Qa 1}

Alluvium--Well to poorly sorted and stratified clay, silt, sand, and gravel. The unit consists of stream-channel, side stream, overbank, fan, and lacustrine deposits and may include some glacial deposits and postglacial terrace gravels.

Q1s

Landslide deposits--Consists of poorly sorted blocks, boulders, gravel, and finer sediments produced by the gravitational failure and rotational-translational slide of bedrock and/or unconsolidated sediments above the bedrock; surfaces are usually hummocky. Most slides are of Holocene age.

Qmt

Trout Lake mudflow--Unsorted mixture of subangular to subrounded boulders in a matrix of sand, silt, and clay, derived from Mount Adams (Hopkins, 1976). The boulders, up to $20 \mathrm{~m}$ in diameter, become finer upward and are primarily andesite from Mount Adams with lesser olivine basalt. The mudflow originated on the southwestern flank of Mount Adams at the head of the White Salmon Glacier and flowed down the White Salmon River valley for $40 \mathrm{~km}$. A radiocarbon age of $5,070 \pm 260$ years was obtained from a tree stump near the base of the unit (Hopkins, 1976).

Qdu

Glacial drift, undifferentiated--Alpine glacial till and outwash of undetermined age. On Mount Adams it is mastly till, dominantly Holocene (Neoglacial) above $1900 \mathrm{~m}$ and late Pleistocene below, except that Holocene moraines extend down to $1525 \mathrm{~m}$ in Big Muddy Creek (Hildreth and others, 1983).

Qde

Qdet

Evans Creek Drift--Glacial drift consisting of till, moraines, and outwash deposits from alpine glaciation (Hammond, 1980). The till (Qdet) is bouldery, loosely compacted, and complexly interbedded with poorly sorted silt, sand, and gravel. A yellowish brown oxidized zone extends to a depth of 0.6 to $0.9 \mathrm{~m}$, and cobbles within the zone do not usually have weathering $r$ inds. 
The outwash deposits are loosely consolidated, stratified, poorly to well-sorted silts, sands, and gravels. The ice accumulation area for this unit was Mount Adams and the Indian Heaven area. Evans Creek Drift in the Mount Rainier area has an age of 13,000 to $24,000 \mathrm{yr}$ b.p. and is probably time equivalent to the drift in the Indian Heaven area.

Qdmr

McDonald Ridge drift--Bouldery till and lesser outwash deposits on the southern slopes of Mount Adams (Hopkins, 1976). The tills are gray, appear fresh, and have a yellowish-brown oxidation zone down to 0.8-1.3 $\mathrm{m}$. Weathering rinds are generally less than 0.5 $\mathrm{mm}$ thick and are often completely absent. The boulders are derived entirely from Mount Adams and consequently cons ist of pyroxene andesite. The till forms several steep-sided, nested moraines, including end moraines in Big Muddy, Hellroaring, and Cascade Creeks, with maximum thicknesses of 25-90 m. Fresh gravelly outwash extends down small creek valleys which drain the end moraines. Hammond (1980) correlates the McDonald Ridge Drift with Evans Creek Drift, 13,000 to 24,000 yr b.p.

Qdh,

Qdh $\mathrm{t}$

Hayden Creek Drift (?)--Glacial till and moraines from alpine glaciation (Hammond, 1980). The till is stony and weathered to a depth of about $2 \mathrm{~m}$. Clasts are partly decomposed, with weathering $r$ inds from $0.5-2.5 \mathrm{~mm}$ thick. This unit was deposited by glaciers with ice accumulation areas at Indian Heaven and Mount Adams and is probably correlative with the Hayden Creek Drift in the Mount Rainier area which is believed to be 130,000-150,000 years old (Porter, 1976; Waitt, 1977).

Qdw

White Salmon drift--stoney till and lesser gravel outwash deposits on the southern side of Mount Adams (Hopkins, 1976). The till is pinkish-gray to light brownish-gray where fresh, and weathers to dark yellowish brown. Oxidation usually extends to depths of 2-3 $\mathrm{m}$, and down to $8 \mathrm{~m}$ near Big Muddy Creek. Weathering rinds are commonly 1-2 mm thick. The till forms ground moraines discontinuously covering the $r i d g e$ between the White Salmon River and Trout Lake Creek, and remnant patches a long the west side of Trout Lake Creek valley. The White Salmon drift is overlain by olivine basalts from Smith Butte and andesite flows from Suksdorf Ridge on Mount Adams. Hammond (1980) suggests a correlation with Hayden Creek Drift, about 130,000 to 150,000 yr b.p. The morainal deposits along the Klickitat River may be from an older glaciation. 
QQ a

Mount Adams andesite--Porphyritic andesite flows and flow breccia forming the Mount Adams stratovolcano (Hopkins, 1976; Hildreth and others, 1983). Medium-gray, bluish-gray, and pinkish-gray pilotaxitic andesite forms blocky flows with platy jointing. Crude columnar jointing occurs locally in many flows, but well developed columnar jointing is restricted to the thickest flows. In thin section, phenocrysts consist of plagioclase, hypersthene, augite, and less common olivine, in a groundmass of plagioclase laths, pigeonite, magnetite, and varying amounts of glass. In many flows, glomeroporphyritic clots of the phenocrysts are common. The flows have constructed a stratovolcano $3,742 \mathrm{~m} \mathrm{high}$, standing about $3 \mathrm{~km}$ above its surrounding base, covers an area of $650 \mathrm{~km}^{2}$, and has a total volume of about $350 \mathrm{~km}^{3}$. The bulk of the present cone is younger than $270,000 \pm 40,000$ yr b.p., based on a whole-rock K-Ar age date for a stratigraphically low flow exposed on the east side of the cone (Hildreth and others, 1983; and sample no. 5 of Table 1). The older andesitic complex, upon which the present cone is built, has been whole-rock K-Ar dated at $400,000 \pm 100,000$ yr b.p., determined for a flow exposed in the Klickitat River canyon (Hopkins, 1976; and sample no. 9 of Table 1). Flows belonging to the older complex are shown separately as Qaao and Qaad (dacite flows). The dacite of Olallie Lake whole-rock K-Ar dated to be $460,000 \pm 30,000$ yr b.p. old, may be an early Mount Adams product (see Qvol). The bulk of the Mount Adams volcanism is late Pleistocene, but minor Recent flows have also been mapped. Holocene andesite flows are shown separately as Qaah.

Qaah

Mount Adams pyroxene andesite (Holocene)--Seven or more eruptions took place over the last 10,000 years since the retreat of the Evans Creek alpine glaciers on Mount Adams. These were flank eruptions of pyroxene andesite and include the A. G. Aiken Lava Bed, Mutt on Creek, Divide Camp (north of Adams Glacier), Cunningham Creek, Trapper Creek, Takh Takh Meadows, and Muddy Fork flows. In addition, the basalt of Red Butte on the northeast flank of Mount Adams is Holocene (see Qvrb for a description). Only the Muddy Fork flow is younger than 3,500 years old, based on stratigraphy with tephra layers from Mount St. Helens.

Qaev

Mount Adams volcaniclastic rocks, debris flow avalanche deposits (Holocene)--Includes some interstratified alluvium and till. 
Qaax

Mount Adams olivine andesite--Aphyric to slightly phyric olivine andesite flows of the main cone.

Qåo

Mount Adams andesite of older complexes--Flows representing the eroded remnants of the older volcanic complexes, erupted from vents now concealed by the present cone (Hildreth and others, 1983). A whole-rock K-Ar age date of $400,000 \pm 100,000$ yr b. p. (Hopkins, 1976; and sample no. 9 of Table 1) was determined for an andesite flow exposed in the Klickitat River canyon.

Qaad

Mount Adams dacite flows-Dacite flows and flow breccia from an early Mount Adams volcano, forming a large portion of the platform upon which the younger andesite stratocone was built.

Qaar

Mount Adams rhyolite--Phyolite exposed along Clearwater Creek; may be part of an earlier silicic volcanoat Mount Adams.

Other volcanic units associated with the Mount Adams stratovolcano and possibly related to it are described separately as basalt of Goat Butte (Qvgb), basalt of Little Mount Adams (Qvlm), basalt of Red Butte (Qvrb), basalt of Riley Creek (Qvri), andesite of South Butte (Qvsb), and basaltic andesite of Snipes Mountain (Qvsn).

Qshu

Mount st. Helens debris flows, older than 2,500 years. Pyroclastic material derived from Mount st. Helens and deposited by debris flow and lahars. Clasts are dominantly gray, pink, and red hornblende-hypersthene dacite and andesite and hornblendehypersthene-plagioclase phyric pumice. Within the map area the unit is restricted to the Lewis River drainage system near House Rock. The unit is very late Pleistocene and Holocene.

Qvb

Basalt flows, unnamed--Basalt flows, flow breccia, and scoria forming isolated monogenetic volcanic cones. These units have not yet been described in any detail. 
Qvbd

Basaltic andesite of Badger Peak--Light-to dark-gray, finegrained microphyric and slightly phyric olivine-augite basaltic andesite flows. Several major element analyses for this unit are shown in Table 2. The flows have been $\mathrm{K}-\mathrm{Ar}$ dated by Jim Smith, USGS and are middle of Pleistocene age.

Qvbk

Basalt of Blue Lake--Medium-gray, dense to vesicular, olivine basalt flow(s) and scoriaceous cone. The Blue Lake volcano erupted within the small Blue Lake Creek drainage, diverting and partially blocking the original creek, forming Blue Lake. The new drainage appears to be a hanging valley relative to the Cispus River, suggesting an age of middle Pleistocene.

Qvbm

Basalt of Bird Mountain--Medium-gray, abundantly phyric, olivine basalt (Hammond, written commun., 1983). The basalt forms a lava flows $1.5 \mathrm{~m}$ thick, with $10-20 \mathrm{~cm}$ interbeds of scoria. They were erupted from a scoria cone on the northern peak of Bird Mountain. The cumulative thickness is $50-60 \mathrm{~m}$, forming an estimated total volume of $0.29 \mathrm{~km}^{3}$. The unit is of middle or late Pleistocene age.

Qvbn

Basalt of Bunnell Butte--Olivine basalt cone and flows north of Smith Butte and northwest of King Mountain. The cone consists of stratified red and black scoriaceous basalt lapilli. The basalt is similar and probably related to the basalt of Camas Prairie from the King Mountain fissure zone and to some of the Smith Butte flows. It is probably of late Pleistocene age.

Qvbp

Basalt of Burnt Peak--Medium-gray, moderately phyric, olivine basalt (Hammond, written commun., 1983). Phenocrysts of plagioclase and olivine are set in fine grained groundmass. The basalt formed subglacial moberg deposits of interstratified pillow lava flows and thin to thick-bedded palagonitic hyaloclastic breccia and tuff (Pederson, 1973). At least six separate vents form topographic highs within the Crazy Hills, the most prominent of which is Burnt peak. The unit has a total thickness of 60-100 m and an estimated volume of $1.71 \mathrm{~km}^{3}$. It was formed during the Evans Creek alpine glaciation between 13,000 and 22,000 yr b.p. 
Qvem

Basalt of Chenamus Lake--A small olivine basalt flow southwest of Bird Mountain atop the basalt of Placid Lake. The source of this flow is not known.

Qveo

Basalt of County Park--Light- to dark-gray phyric olivine basalt (Hopkins, 1976). This unit originally comprised many different basalt flows on the south side of Mount Adams that are older than part of the main cone (about 240,000 yr b.p. to present) and older than the King Mountain fissure zone flows (basalt of Camas Prairie and basalt of Smith Butte, about 300,000 to 100,000 yr b.p.). Although they were erupted from several different sources, Hopkins (1976) grouped the flows into a single unit because of general similarities, and for convenience. A series of flows occur along the White salmon River which were originally included with Hopkins' basalt of County Park, but are now informally called basalt of Green Canyon (Qvgr) (Hammond and Korosec, 1983) and basalt of Gotchen Creek (Qvgo) (this report). This leaves only two areas designated Qvco, southeast of Snowplow Mountain along Dry Creek, and between Bacon Creek and Dairy Creek. These units were described as appearing similar to the basalt of Simcoe Mountains (QTsb), and may indeed be Pliocene Simcoe basalt.

Qvep

Basalt of Camas Prairie--Medium- to dark-gray olivine basalt (Sheppard, 1964). Intracanyon pahoehoe lava flows, generally 3-6 $m$ thick, were erupted from several vents of the shield volcano at King Mountain. They form the valley floor at Camas Prairie and the west side of part of the Klickitat River canyon. The lava flows are blocky jointed, with basal breccia and vesicular to scoriaceous tops (Hammond, 1980). In thin section, the basalt is holocrystalline, diktytaxitic, and porphyritic, with plagioclase and olivine phenocrysts in a groundmass of plagioclase, clinopyroxene, olivine, and opaque minerals. The olivine is commonly glomeroporphyritic with partial replacement by iddingsite. At Camas Prairie, the flows have flooded the valley, and are now covered with sporadic patches of silt and sand, up to $30 \mathrm{~cm}$ thick. In the Klickitat River canyon, numerous nested flows of 3-10 m thickness have an accumulative thickness of more than $120 \mathrm{~m}$. Whole-rock K-Ar age dates on these flows give approximate ages of $300,000 \pm 80,000$ yr b.p. and $100,000 \pm$ 100,000 yr b.p. (Shannon and $\bar{W}$ ilson, 1973 ; and sample no. 1 and no. 6 of Table 1 ). 
Qude

Basalt of Deep Lake--Light-gray, moderately phyric augiteplagioclase-olivine basalt (Hammond, written commun., 1983). Phenocrysts are set in a fine-grained granular groundmass. The basalt forms blocky jointed flows, 6-25 m thick, with scoria interbeds up to $50 \mathrm{~cm}$ thick. Two flows are preserved on the west slope of Bird Mountain. They were erupted from a vent on the southeast flank of Bird Mountain. In addition, three flows erupted from this vent flowed eastward across the north slope of the Lemei Rock volcano into the Trout Lake Creek canyon. These flows have a maximum thickness of $25 \mathrm{~m}$. The cumulative volume of the unit is about $1.3 \mathrm{~km}^{3}$. The basalt of Deep Lake has a probable middle or late Pleistocene age, suggested by its stratigraphic position.

Qvdh

Basalt of Dead Horse Creek--Dark-to medium-gray, abundantly phyric olivine basalt (Hammond, written commun., 1983). Phenocrysts of plagioclase, olivine, and hypersthene are in a fine-grained groundmass. The basalt forms a blocky intracanyon lava flow, 6-35 m thick. It's total volume is about $0.03 \mathrm{~km}^{3}$. The age of this unit is late Pleistocene, younger than the Hayden Creek alpine glaciation (less than 130,000 yr b.p.).

Qvec

Basalt of East Canyon Creek--Scoriaceous olivine basalt with yellow, red, and brown cinders and lapilli tuff forming two cinder cones southwest of the confluence of the Cispus $R$ iver and East Canyon Creek. The northern cone is $130 \mathrm{~m} \mathrm{high,} \mathrm{and} \mathrm{the}$ southern cone is $180 \mathrm{~m} \mathrm{high}$. The tuff appears to be hyaloclastites in part, suggesting a subglacial eruption. The cones are overlain by a thin gray columnar jointed basalt flow which was erupted through the top of the cinder cones. The basalt is highly vesicular, consisting of plagioclase, olivine, minor pyroxene, and a glassy matrix. The preservation of the cones within a glacial valley suggests that the eruptions took place during or after the last major alpine glaciation, Evans Creek, at about 13,000 to 24,000 yr b.p.

Qve 1

Basaltic andesite of Eunice Lake--Light- to medium-gray vesicular to dense phyric plagioclase-olivine basaltic andesite and aphyric andesite (Hammond, written commun., 1983). Numerous blocky to platy jointed flows $1-12 \mathrm{~m}$ thick are commonly separated by interbeds of scoria $0.5 \mathrm{~m}$ thick, attaining a maximum thickness of $140 \mathrm{~m}$ and an approximate volume of $2.0 \mathrm{~km}$. The flows may have erupted from a zone of east-west dikes at North Gifford Peak, south of the map area. The probable age is middle Pleistocene. 


\section{Qvfm}

Basalt of Flattop Mountain--Light-gray aphyric olivine basalt (Hammond, 1980). Vesicular to scoriaceous blocky lava flows, originating from several sources, including the base of a cinder cone atop Flattop Mountain, have a maximum thickness of $50 \mathrm{~m}$. The age is unknown, but is probably middle to late Pleistocene.

\section{Qvga}

Basalt of Glaciate Butte--Olivine basalt. The basalt eipted from a vent at Glaciate But te on the northeast flank of Mount Adams and flowed north-northeast along the Clearwater Creek drainage. The unit has an age of late Pleistocene, possibly Holocene.

\section{Qvgo}

Basalt of Gotchen Creek--Light- to dark-gray phyric olivine basalt. These flows were included in the County Park olivine basalt by Hopkins (1976). Moderately abundant phenocrysts of olivine and plagioclase are set in a fine-grained, diktytaxitic groundmass of plagioclase laths, olivine, clinopyroxene, opaque minerals, and minor glass. The basalt forms several lava flows, 3-6 $\mathrm{m}$ thick, erupted from an unnamed butte between Gotchen Creek and the White Salmon River, and possibly from vents north of this butte that are now concealed by andesite flows from Mount Adams. Whole-rock K-Ar ages for this unit are $0.20 \pm 0.034$ and $0.24 \pm$ $0.71 \mathrm{m.y}$. (Hammond and Korosec, 1983; and sample no. 3 of Table 1).

\section{Qvgr}

Basalt of Green Canyon--Medium- to light-gray, generally aphyric, olivine basalt (Hammond, 1980, for "basalt of Little Deer Point"). The basalt forms a series of dense lava flows 3-30 m thick, with blocky to columnar jointing. They were erupted from multiple centers, including vents located at Cakey Butte and an unnamed butte northwest of Cakey Butte. The flows have a cumulative maximum thickness of $100 \mathrm{~m}$. These flows were included in the "basalt of County Park" by Hopkins, (1976). The age of this unit is probably middle pleistocene.

\section{Qvgt}

Basalt of Goat Butte--Phyric olivine basalt, forming a cone of ejecta and lava on the east flank of Mount Adams (Hildreth and others, 1983). Mulligan Butte, near the center of the lava field, is also a volcanic vent. The unit is of late Pleistocene age and younger than the main cone of Mount Adams. 
Qvil

Basalt of Hidden Lake--Light- to medium-gray, moderately phyric, olivine basalt (Hammond, written commun., 1983). Phenocrysts of plagioclase and olivine are set in a dense, very fine-grained granular groundmass. The basalt forms a and pahoehoe lava flows, 1-8 m thick, with 0.5-3 m thick scoriaceous zones separating flows. The total thickness is $60-75 \mathrm{~m}$, with an estimated volume of $11.5 \mathrm{~km}^{3}$. Most of the Lemei Rock volcano consists of the basalt of Hidden Lake. The unit has a probable age of late Pleistocene, suggested by its stratigraphic position.

Qvic

Basalt of Ice Caves--Gray, abundantly phyric, olivine basalt (Hammond, written commun., 1983). In thin section, phenocrysts of plagioclase and olivine are in a diktytaxitic holocrystalline groundmass of plagioclase, olivine, and opaque minerals. The plagioclase phenocryst are generally glomerocrysts of radiating laths. The basalt forms blocky-jointed pahoehoe lava flows, 0.5 $-6 \mathrm{~m} \mathrm{thick}$. They were erupted from the crater at Lake Wapiti of the Lemei Fock volcano, and flowed down the east flank. One lobe flowed to the northeast of Trout Lake Creek. Most of the flow went south and east (south of the map area), into the white Salmon River canyon at Trout Lake, and down the canyon at least $43 \mathrm{~km}$ to Husum. The flow has a thickness of 10-12 m and an estimated volume of $1.2 \mathrm{~km}^{3}$. It is younger than Hayden Creek glaciation $(130,000$ to 150,000 yr b.p.), late Pleistocene age.

\section{Qvih}

Basalt of Indian Heaven--Light-gray, abundantly phyric, olivine basalt (Hammond, written commun., 1983). Phenocrysts consist of randomly oriented plagioclase crystal plates, isolated glomerocrysts of radiating plagioclase plates, and olivine. The groundmass is diktytaxitic, with plagioclase, olivine, and opaque minerals. The basalt forms blocky-jointed pahoehoe lava flows 1 $-3 \mathrm{~m}$ thick, with $1-3 \mathrm{~m}$ thick interbeds of scoria. Numerous flows erupted from a bocca on the west side of the $120 \mathrm{~m} \mathrm{high} \mathrm{East}$ Crater, just south of the maparea, and flowed down the west slope, reaching the upper Wind River valley, and extending downvalley to the Tyee Springs area, northeast of Trout Creek Hill. The flows reach a cumulative maximum thickness of $24 \mathrm{~m}$, and have a total volume of approximately $0.5 \mathrm{~km}^{3}$. The age is late Pleistocene, with the East Crater activity post-dating the basalt of Lake Concomly (Qvlc), a 30,000 yr b.p. flow (Hammond, 1985, written commun.). 
Qviv

Basalt of Indian Viewpoint--Light- to medium-gray, abundantly phyric, olivine basalt (Hammond, written commun., 1983). Phenocrysts of plagioclase, olivine, and minor augite are in a very fine grained, pilotaxitic to equigranular groundmass. The basalt forms thick, scoria-fed a lava flows 1.5-4.0 m thick, with 15-150 cm thick interbeds of scoria. The flows reach a cumulative total thickness of $60 \mathrm{~m}$, and have a volume of about $6 \mathrm{~km}^{3}$. They erupted from a vent at Bird Mountain in the late Pleistocene, probably before Hayden Creek alpine glaciation.

QV1b

Basalt of Lone Butte--Medium-gray, moderately phyric, olivine basalt (Hammond, written commun., 1983). Lone Butte is a $400 \mathrm{~m}$ high tuya "composed of foreset-bedded pillow-lava breccia with interstratified, thin- to thickly-bedded, locally palagonized hyaloclastic breccia and tuff, overlain by $73 \mathrm{~m}$ of subaerial scoriaceous lava, and capped by a $60 \mathrm{~m}$ dissected cone of scoriaceous agglutinate" (Hammond, written commun., 1983). The total volume of Lone Butte is about $0.3 \mathrm{~km}^{3}$. It was erupted either during the Hayden Creek alpine glaciation (130,000-150,000 yr b.p.) or Evans Creek alpine glaciation $(13,000-24,000$ yr b.p.) and may be related to the subglacial mobergs of the basalt of Burnt Peak (Qvbp).

Qvlc

Basalt of Lake Comcomly--Dark gray, sparsely phyric, olivine basalt (Hammond, written commun., 1983). Glomerocrysts of plagioclase phenocrysts surrounding olivine phenocrysts are in a fine grained groundmass of plagioclase, olivine, and opaque minerals. The basalt forms pahoehoe lava flows, 0.5-12 $\mathrm{m}$ thick, with scoriaceous margins, pillow lava, breccia, and abundant tumuli. The cumulative thickness is $2-30 \mathrm{~m}$, and the estimated volume is about $1.3 \mathrm{~km}^{3}$. The lava was erupted from the southeast crater of the Lemei Rock volcano, marked by a $120 \mathrm{~m} \mathrm{high} \mathrm{scoria}$ and spatter cone, and descended the east and west "flanks" of Indian Heaven. The eruptions occurred in late Pleistocene time, probably during an unnamed glaciation which Hammond (written commun.) speculated to have taken place about 30,000 yr b.p.

Qvif

Basaltic andesite of The Loaf--Light- to medium-gray, phyric, olivine-pyroxene basalt. The flow(s) erupted from a vent near the top of The Loaf and flowed to the southwest. The total thickness is greater than $100 \mathrm{~m}$. The age of the unit is not known. 
Qvlg

Basalt of Little Goose Creek--Light-gray, sparsely phyric, olivine basalt (Hammond, written commun., 1983). Olivine phenocrysts are set in a pilotaxitic groundmass of primarily plagioclase and olivine. The basalt forms blocky jointed lava flows, $4-12 \mathrm{~m}$ thick, with scoriaceous zones separating individual flows. The maximum cumulative thickness is $73 \mathrm{~m}$, and the volume is approximately $11.5 \mathrm{~km}^{3}$. This unit forms the basal part of the Lemei Rock volcano and is stratigraphically confined to be about 200,000 to 500,000 yr b.p.

Qvlk

Basalt of Lakeview Mountain--Gray, phyric, olivine-hypersthene basalt (Hammond, 1980). The basalt forms dense, flow-layered, platy-jointed lava flows $6-10 \mathrm{~m} \mathrm{thick}$. The total thickness is est imated to be $300 \mathrm{~m}$. The flows erupted from a central vent at the top of Lakeview Mountain and formed a broad shield volcano which has since been deeply dissected by glaciers. This unit is probably of middle Pleistocene age.

Qvim

Basaltic andesite of Little Mount Adams--Phenocryst-poor olivinebearing basaltic andesite (Hildreth and others, 1983). Ejecta and lava flows form a late Pleistocene volcanic center on the southeast flank of Mount Adams.

Qume

Basaltic andesite of Meadow Creek--Medium-gray, moderately phyric, olivine basaltic andesite (Hammond, written commun., 1983). Phenocrysts of plagioclase and olivine are set in $a$ dense, very fine grained pilotaxitic groundmass. The basaltic andesite forms blocky flows, 2-13 m thick, with a total cumulative thickness of $122 \mathrm{~m}$, and an estimated volume of 3.4 $\mathrm{km}^{3}$. The unit underlies a part of Sawtooth Mountain, the source of the basalt of Sawtooth Mountain, K-Ar dated to be $850,000 \pm$ 50,000 yr b. P. An unpublished whole-rock K-Ar age date of 1.21 $\pm 0.05 \mathrm{~m} . \mathrm{y}$. has been reported by Paul Hammond in a $1985 \mathrm{field}$ trip guide to the Indian Heaven volcanic field (sample no. 29 of Table 1 ).

Qvml

Basalt of McClellan Meadows--Medium-gray, phyric, olivine basalt. Phenocrysts of plagioclase and olivine are set in a diktytaxitic groundmass of plagioclase, olivine, and clinopyroxene. The flows form part of the western margin of the Indian Heaven volcanic fieldand are partially lapped by flows of the basalt of Indian 
Heaven (Qvih). The source and age of the McClellan Meadows flows are not known.

\section{Qvmq}

Basalt of Mosquito Creek (also known as basalt west of steamboat Mountain)--Olivine basalt flows and scoria (Hammond, 1980). Flows and scoria form three cones on the lower west flank of Steamboat Mountain. The surfaces of the flows are free of glacial deposits, suggesting an age younger than Evans Creek alpine glaciation, less than 13,000 to 20,000 yr b.p.

\section{Qvoc}

Basalt of Outlaw Creek--Medium-gray, sparsely phyric, olivine basalt (Hammond, written commun., 1983). Phenocrysts of plagioclase and olivine are in a fine-grained, equigranular groundmass of plagioclase, olivine, and opaque minerals. The basalt forms blocky jointed lava flows 3-8 m thick, separated by scoria interbeds up to $1 \mathrm{~m}$ thick. The thickest exposure of the flows is $26 \mathrm{~m}$. The source of the basalt is not known. These flows are stratigraphically the lowest known unit of the Indian Heaven volcanic field, indicating a Pliocene to early Pleistocene age. These flows are not the lowest unit in the Indian Heaven volcanic field, indicating a Pliocene to early pleistocene age.

\section{Qvol}

Dacite of Olallie Lake--Dark-gray, porphyritic, two-pyroxene dacite flows. Phenocrysts of plagioclase, hypersthene, and augite are set in an intergranular groundmass of plagioclase, pyroxenes, magnetite, and glass. The flows have brecciated bases, columnar jointed to platy centers, and blocky tops. The source is unknown, and may be concealed by younger andesite flows from the Mount Adams stratovolcano. Hildreth and others (1983) believe that this unit may represent an early phase of volcanism from Mount Adams. Whole-rock K-Ar age dates of 460,000 $\pm 20,000$ and $470,000 \pm 40,000$ yr b.p. were determined for this unit (Hildreth and others, 1983; and sample no. 10 of Table 1 ).

\section{Qvos}

Andesite of Old Snowy Mountain--Light-gray, phyric, hypersthene andesite (Hammond, 1980). Very fine grained, dense, andesite forms at least four lava flows in the upper Cispus River valley. The flows are platy to blocky jointed with scoriaceous bases, 10$30 \mathrm{~m}$ thick. The cumulative thickness is about $100 \mathrm{~m}$. The flows erupted from vents near the top of old Snowy Mountain just north of the map area. This vent area was also the center of the Pliocene Goat Rocks stratovolcano. The andesite of Old Snowy Mountain may be related to the Tieton Andesite, which was erupted 
about $1 \mathrm{~m} . \mathrm{y}$. ago (K-Ar age date) from vents just east of the old Snowy vents (Clayton, 1983).

Qvpf

Basalt of Paradise Falls--Olivine basalt. The basalt forms an isolated small shield volcano northwest of the Indian Heaven volcanic field. A whole-rock $\mathrm{K}-\mathrm{Ar}$ age date of $40,000 \pm 30,000$ yr b.p. was determined for this unit (Hammond and Korosec, 1983; and sample no. 1 of Table 1 ).

Qvph

Basaltic andesite of Potato Hill--Medium- to dark-gray phyric, olivine basalt (Hammond, 1980). The basalt formed several thin lava flows, 1-3 m thick, with a maximum cumulative thickness of $10 \mathrm{~m}$. Flow tops and bottoms are scoriaceous. The flows originated at Potato Hill, a well preserved cinder cone. Because the cone has not been modified by glaciation, the unit is probably of late Pleistocene age.

\section{Qvp 1}

Basalt of Placid Lake--Light- to medium-gray, moderately phyric, olivine basalt (Hammond, written commun., 1983). Phenocrysts of olivine are in a fine grained granular groundmass of plagioclase and olivine. The basalt forms blocky jointed lava flows $0.5-8 \mathrm{~m}$ thick, with a maximum cumulgtive thickness of $155 \mathrm{~m}$ and an approximate volume of $5.8 \mathrm{~km}^{3}$. The flows were erupted from a zone of dikes west of Bird Mountain. The stratigraphic position of this unit suggests an early pleistocene age.

Qvrb

Basalt of Red Butte--Olivine basalt (Hildreth and others, 1983). The lava was erupted from a vent at Red Butte on the northeast flank of Mount Adams and flowed along the Clearwater Creek and Trappers Creek drainages. The cone at the vent consists of scoria and agglutinate. The unit has a Holocene age.

Qvrc

Basalt of Rush Creek--Medium-gray, sparsely to moderately phyric, augite-olivine basalt (Hammond, written commun., 1983). Pahoehoe l'ava flows, 1-10 m thick, are commonly separated by interbeds of scoria $0.2-2 \mathrm{~m}$ thick. The flows have a maximum cumulative thickness of $370 \mathrm{~m}$ and an estimated volume of $4.75 \mathrm{~km}^{3}$. The exact source of these flows is unknown, and is probably concealed by the younger flows near the center of the Indian Heaven volcanic field. The basalt of Rush Creek may correlate with the 
basalt of Dry Creek south of the map area. Both have stratigraphic positions which suggest that they have a probable middle Pleistocene age.

\section{Qvri}

Basalt of Riley Creek--Sparsely phyric, olivine basalt (Hildreth and others, 1983). The basalt forms a flow along the Riley Creek drainage on the west flank of Mount Adams. The source vent has been covered by Holocene volcaniclastic rocks and glacial debris. The unit is of late Pleistocene age.

Qvi 1

Basalt of Red Lake--(Basaltic cone northwest of Sawtooth Mountain, Hemmond, written commun., 1983). Dark-gray, sparsely phyric, olivine basalt. The basalt consists of scoria, spatter, and a lava lenses forming a broad craterless cone $12 \mathrm{~m} \mathrm{high}$. The cone has been partially eroded during Evans Creek glaciation, from a glacier heading on Sawtooth Mountain. The unit is of late Pleistocene age.

Qvis

Andesite of South Butte--Slightly phyric, olivine andesite (Hildreth and others, 1983). The andesite forms a lava flow and a cone of near-vent ejecta at South Butte on the south flank of Mount Adams. The unit is of late Pleistocene age. The Holocene andesite flow of the A. G. Aiken Lava Bed (Qaah) erupted from a vent on the south side of South Butte. Both flows are part of the Mount Adams stratovolcano system.

Qvsc

Basalt of Spring Creek--Dark-gray phyric, hypersthene-olivine basalt (Hammond, 1980). The basalt forms a series of scoriaceous blocky jointed lava flows $2-4 \mathrm{~m}$ thick. The flows erupted from an unnamed butte north of Mount Adams $(2 \mathrm{~km}$ southeast of Potato Hill) and advanced westward into the Cispus River valley and eastward into the Klickitat River valley. Remnants of the extensive flow in the Cispus River valley are found as far away as Bishop Mountain, at the confluence of the Cispus and North Fork Cispus Rivers. Major element analyses of this flow from several areas are shown in Table 2. The unit has a late Pleistocene age. 
Qvsg

Andesite of Signal Peak--Dark-gray, glomeroporphyritic, olivinepyroxene andesite (Sheppard, 1967; Hammond, 1980). Phenocrysts of zoned plagioclase, olivine, hypersthene, and clinopyroxene are in a groundmass of plagioclase, clinopyroxene (pigeonite and augite), opaque minerals, and glass. The olivine and hypersthene phenocrysts typically have reaction $r$ ims of clinopyroxene. Plagioclase phenocrysts commonly form glomerocrysts. The flows are 3-9 $\mathrm{m}$ thick and form a steep-sided volcano south of the Lincoln Plateau, centered at Signal Peak. The age of this unit is uncertain. The andesite is younger than the PliocenePleistocene basalt of Lincoln Plateau and is probably early Pleis tocene.

Qvsh

Basalt of Spud Hill--Red and black scoriaceous basalt. Highly scoriaceous, nearly aphanitic basaltic tephra and agglutinate form a cinder cone on the south side of spud Hill, near the contact of the intrusive rhyolite and volcaniclastic country rock. The unit is of late Pleistocene age, possibly Holocene age.

Qvsk

Basalt west of Skull Creek-Dark-gray, moderately phyric, olivine basalt (Hammond, written commun., 1983). Olivine phenocrysts are set in a dense, very fine grained groundmass. The basalt forms blocky jointed to columnar jointed lava flows along Trout Lake Creek. The total cumulative thickness is 35 to $75 \mathrm{~m}$ and estimated volume $0.8 \mathrm{~km}^{3}$. The source vents for the flows form a ridge on the west side of sleeping Beauty. A whole-rock K-Ar age date of $1.34 \pm 0.02 \mathrm{~m} . \mathrm{y}$. was determined for the unit (Hammond and Korosec, 1983 ; and sample no. 14 of Table 1 ).

Qvsm

Basalt of Smith Butte--Dark-gray, phyric to aphyric, olivine basalt (Hopkins, 1976; Hammond, 1980). Phenocrysts consist of olivine (without reaction or alteration rims) and minor plagioclase. The groundmass is a network of subparallel plagioclase laths with interstitial clinopyroxene, magnetite, glass, and olivine. Basalt forms a complex of lava flows 1.5-4.0 m thick, with a cumulative thickness of at least $45 \mathrm{~m}$. The lava consists of a high percentage of scoriaceous breccia. The flows were erupted from numerous vents, several of which are marked by cinder cones, the most prominent of which is Smith Butte. The cones are composed of stratified red, gray, and black scoriaceous basalt lapilli with minor bombs and ash. The surfaces of the flows show only sight erosional modification. Pressure ridges, lava channels, flow edges, and other primary flow features are 
well preserved. A poor-quality whole-rock $\mathrm{K}-\mathrm{Ar}$ age date of $0.1 \pm$ $0.1 \mathrm{~m} . \mathrm{y}$. was determined for a flow on the east side of Smith Butte (Shannon and Wilson, 1973; and sample no. 2 of Table 1 ). The age of the unit is late Pleistocene and may include some Holocene flows.

\section{Qvsn}

Basaltic andesite of Snipes Mountain--Dark-gray, slightly phyric, olivine basaltic andesite (Hildreth and others, 1983). The basaltic andesite forms flows and a cinder cone of ejecta on the lower south flank of Mount Adams. The unit has a late Pleistocene age, based on its stratigraphic position.

Qvsq

Basalt of Squaw Butte--Olivine basalt forms a small volcanic center on the southwest flank of Squaw Butte (Hammond, 1980; Hammond, personal commun., 1986). The age of this unit is unknown .

Qvst

Basalt of Sawtooth Mountain (Basalt of Surprise Lakes)--Lightgray, moderately phyric, olivine basalt (Hammond, written commun., 1983). The basalt consists of phenocrysts of plagioclase and olivine in a dense, very fine-grained pilotaxitic to equigranular groundmass. The lava flows are blocky to slabby jointed, 1-4 m thick, with scoria interbeds 20-50 cm thick. The greatest cumulative thickness is $79 \mathrm{~m}$, and the total volume is estimated to be $3.6 \mathrm{~km}^{3}$. The Sawtooth Mountain volcano was the source of these flows. A whole-rock K-Ar age date of $0.85 \pm 0.05$ m.y. was determined for this unit (Hammond and Korosec, 1983; and sample no. 12 of Table 1 ).

\section{Qvsw}

Andesite of Swampy Meadow--Light-gray, phyric, hypersthene andesite (Hammond, 1980). Dense, fine-grained, and platy jointed flows are 2-10 m thick. The cumulative thickness is $80 \mathrm{~m}$, and the approximate volume is about $0.23 \mathrm{~km}^{3}$. The source of these flows is probably buried by younger andesite flows from Mount Adams. A whole-rock K-Ar age date of $370,000 \pm 10,000$ yr b.p. was determined for the unit (Hammond and Korosec, 1983; and sample no. 8 of Table 1). The andesite of Swampy Meadow may be an early flow from Mount Adams. 
Qvsy

Basalt of Sleeping Beauty--Medium-gray, slightly phyric, olivine basalt (Hammond, written commun., 1983). Fiows were erupted from a vent on the south side of sleeping Beauty and form a bench on the east side of Trout Lake Creek. The age of the unit is unknown, but is suspected to be middle Pleistocene.

\section{Qvtb}

Basalt of Twin Buttes--Medium- to dark-gray, phyric, olivine basalt (Hammond, 1980). Vesicular to scoriaceous, blocky jointed flows form the summits of East Twin Butte and West Twin Butte. The total cumulative thickness of the flows is $30-120 \mathrm{~m}$. The flanks of the buttes are composed of a high percentage of cinders. The unit's stratigraphic position suggests a middle Pleistocene age.

\section{Qutc}

Basalt of Tillicum Creek--Olivine basalt (Hammond, written commun., 1985). The basalt forms pillowed lava flows and hyaloclastites. It is the most mafic unit of the Indian Heaven volcanic field. The flows may have been erupted near the margin of a glacier originating at the topographically high "plateau" of Indian Heaven and possibly extending into the Lewis River drainage. A whole-rock K-Ar age date of 470,000 $\pm 40,000$ yr b.p. (Hammond and Korosec, 1983; and sample no. 11 of Table 1) suggests that that the glaciation may coincide with Wingate alpine glaciation.

\section{Qvih}

Basalt of Thomes Lake--Light-gray, abundantly phyric, augiteolivine basalt (Hammond, written commun., 1983). Phenocrysts consist of randomly oriented platelets of plagioclase and granular augite and olivine, in a diktytaxitic groundmass. The basalt forms blocky jointed pahoehoe lava flows $1-7 \mathrm{~m}$ thick, erupted from fissures at the south end of East Crater, just south of the map area. Erosion has exposed the feeder dike. The unit has an average cumulative thickness of $37 \mathrm{~m}$ and an estimated volume of $4.0 \mathrm{~km}^{3}$. A whole-rock K-Ar age date of $3.7 \pm 0.5 \mathrm{~m}$. y. was determined for this unit north of the map area (Hammond and Korosec, 1983; and sample no. 15 of Table 1). The basalt of Thomas Lake is one of the oldest units of the Indian Heaven volcanic field, but may not be as old as the age date. Accumulated volume to time models for the Indian Heaven volcanic field suggest the age should be 1.5 to $2.0 \mathrm{~m} . \mathrm{y} .$, assuming a steady rate of volcanism over time. 


\section{Qvt 1}

Basalt of Trout Lake Creek--Light-gray, moderately phyric, augite-olivine basalt (Hammond, written commun., 1983). Phenocrysts of plagioclase, olivine, and augite are set in a diktytaxitic groundmass. The basalt forms pahoehoe lava flows 1$10 \mathrm{~m}$ thick with no interbeds. The source of the flows is unknown. The flows have a maximum cumulative thickness of $35 \mathrm{~m}$ and an approximate preserved volume of $2.8 \mathrm{~km}^{3}$. A whole-rock $\mathrm{K}$ Ar age date of $980,000 \pm 120,000$ yr b.p. (Hammond and Korosec, 1983 ; and sample no. 13 of Table 1) was determined for the unit, but the remanent magnetic polarity is normal.

Qvto

Basalt of Two Lakes--Dark-gray phyric olivine-augite basalt and light-gray phyric olivine basalt (Hammond, 1980). Phenocrysts include plagioclase, augite, and olivine. The lava flows are blocky, to locally columnar jointed, $3-15 \mathrm{~m}$ thick, with scoriaceous tops and bases and interbeds of scoria. The maximum cumulative thickness is at least $150 \mathrm{~m}$. The flows were erupted from several centers, forming an irregular shield. A whole-rock $\mathrm{K}-\mathrm{Ar}$ age date of $350,000 \pm 60,000$ yr b.p. was determined for the unit (Hammond and Korosec, 1983; and sample no. 7 of Table 1 ).

Qvw1

Basalt of Walupt Lake--Dark-gray, phyric, olivine basalt (Hammond, 1980). The basalt forms a volcanic pile consisting of $60 \mathrm{~m}$ of bedded palagonitic tuff capped by $15 \mathrm{~m}$ of subaerial vesicular lava flows with scoria interbeds. The sequence has been interpreted to represent a subglacial volcano which may have formed during Evans Creek glaciation $(13,000$ to 24,000 yr b.p. The base of the volcano predates the glaciation. The total thickness of the unit is $200 \mathrm{~m}$.

\section{Pliocene and Rleistocene Intrusive Rocks}

Qi a

Andesite plugs and dikes--Hypabysal intrusive hornblende andesite exposed northwest of Gilbert Peak in the Goat Rocks area. The intrusions represent the feeders to the hornblende andesite flow(s) which form Gilbert Peak and the ridge crest to the southeast. 
QTia

Andesite domes, plugs, and dikes--Hypabyssal intrusive pyroxene andesite, pyroxene basaltic andesite, and hornblende andesite in the Goat Rocks region are related to the late Pliocene to early Pleistocene volcanism which produced the Goat Rocks stratovolcano (Swanson and Clayton, 1983).

\section{Pliecene=Pleistocene Yolconic Rocks}

QTva

Andesite flows--Ridge capping andesite flows along the Klickton Divide. Very little information is known about this unit. It may be part of the Goat Rocks volcano (see QTvg).

\section{QTvb}

Basalt flows--Unnamed basalt flows, primarily olivine basalt, forming broad shield volcanoes, valley filling flows, and $r$ idge capping remnant flows. The basalt may be related to the basalt of Lincoln Plateau (see QTVl) and/or the basalt of Simcoe Mountains (see QTsb).

QTvd

Dacite flows--Gray, porphyritic, hornblende-pyroxene dacite (Winters, 1984). Phenocrysts of plagioclase (andesine), hypersthene, oxyhornblende, and augite, and inclusions of plagioclase, altered hornblende, and brown glass, are in a groundmass of plagioclase, augite, magnetite, pigeonite, and glass. North of Jordan Creek, the dacite forms a columnarjointed flow interpreted to be an erosionally isolated intracanyon flow from the Goat Rocks volcano (see QTVg).

\section{QTV1}

Basalt of Lincoln Plateau--Gray, cumulophyric, olivine basalt (Sheppard, 1967). Olivine phenocrysts are set in a groundmass of plagioclase, clinopyroxene, olivine, magnetite, and glass. Glomeroporphyritic clots of olivine phenocrysts are common. The olivines are partly altered to iddingsite. The basalt forms flows 3-6 m thick, with a cumulative thickness of at least $120 \mathrm{~m}$. The flows erupted from several different centers, forming a coalesced shield volcano at Lincoln Plateau. The age of the unit is undetermined, but distal flows overlap some flows of the basalt of Simcoe Mountains (QTsb), and Hammond (1980) states that the Lincoln Plateau flows appear younger than Simcoe flows. 


\section{QTsb}

Basalt of the Simcoe Mountains (Pliocene to lower Pleistocene)-Gray to gray-black, fine-grained, aphyric to slightly porphyritic, olivine basalt flows and flow breccia (Sheppard, 1967 ; Anderson, written commun., 1985). Surfaces weather to light brown to pale yellowish brown. Flows are occasionally glassy. Thin sections commonly show a trachytic texture, with rare to abundant plagioclase and olivine phenocrysts in a nearly holocrystalline groundmass of plagioclase, clinopyroxene, olivine, magnetite, and apatite. Individual flows are $1-13 \mathrm{~m}$ thick and form stacked flow sequences with thicknesses up to 220 m. Older intracanyon flows usually have well developed colonnades and entabulatures. Younger flows are thinner with columnar jointing. They were erupted from vents on the flanks of shield volcanoes. Cinder cones, up to 45-90 m high, consist of poorly sorted, generally unconsolidated, stratified scoria. They often are aligned along northwest-trending zones. Remanent magnetism has both reversed and normal polarity. K-Ar age dates for flows outside the map area to the east and southeast range from 1.0 to 4.7 m.y., with most flow ages confined to 2.5 to 4.5 $\mathrm{m} \cdot \mathrm{y} \cdot$

\section{QTvg}

Andesite of Goat Rocks--Gray, porphyritic, pyroxene andesite, basaltic andesite, hornblende andesite, and minor dacite flows and flow breccia (Hammond, 1980; Swanson and Clayton, 1983). Phenocrysts usually include plagioclase, hypersthene, and augite, and some flows include hornblende. The flows are generally fresh, with vesicular tops and massive, columnar jointed centers, but locally are hydrothermally altered. The flows and minor interbedded volcaniclastic rocks are the remnants of the Goat Rocks stratovolcano, centered just north of the map area. Thick sequences of shallow dipping valley-filling flows are preserved as $r$ idge capping units due to inverted topography. Age dating and magnetostratigraphy of Goat Rocks flows north of the map area show this unit to range from about 3 to $1 \mathrm{~m} . \mathrm{y}$.

\section{Tertiary Stratified Rocks}

\section{Pvt}

Pliocene tuff and tuff breccia--At Midway Creek, the Midway tuff (Hammond, 1980) is brownish-black welded dacitic lithic-crystalvitric tuff. The unit weathers to olive-gray. The crystals are primarily plagioclase and augite. The lower $3 \mathrm{~m}$ of the unit is nonwelded and poorly consolidated, leading to cavernous weathering. The exposed thickness of the tuff is $23 \mathrm{~m}$. A pair of $\mathrm{K}-\mathrm{Ar}$ age dates for plagioclase separates from the Midway tuff gave ages of $3.6 \pm 0.4 \mathrm{~m} . \mathrm{y}$. and $3.7 \pm 0.4 \mathrm{~m} . \mathrm{y}$. (Hammond, 1980 ; and sample no. 16 of Table 1). Near Cultus Hole, the tuff is 
rhyolitic, vitric, and pumiceous. White rhyolite or rhyodacite tuff north of the Klickton Divide at South Fork Tieton River and Tenday Creek may be distal facies of the Devil's Horns rhyolite $(s$ ee $P d v)$.

$\operatorname{Pdv}$

Devil's Horns rhyolite (Pliocene)--High-silica rhyolite domes, ash-flow tuff, air fall tuff, and volcaniclastic breccia

(Clayton, 1983; Swanson and Clayton, 1983). The unit was erupted from a caldera centered at Devils's Horns just north of the map area. The outcrops within the map area are part of a $650-\mathrm{m}-$ thick, near-vent sequence of mostly non-welded pyroclastic flows. The basal portion of the sequence consists of massive, 100- to 200-m-thick, white, pumice lapilli, vitric ash tuff, and bedded vitric ash tuff. The middle section is characterized by surge deposits, with cross bedded vitric-lapilli and ash tuffs and a 200-300-m-thick section of graded obsidian-block breccias that have filled channels cut into the bedded tuffs. The blocks are up to several meters across. The upper section consists of obsidian-lapilli ash tuff, obsidian-block tuff, thin-bedded pumice-lapilli tuffs $0.1-1 \mathrm{~m}$ thick, and 1-10 $\mathrm{cm}$ thick layers of vitric ash. Zircon fission-track ages of $3.20 \pm 0.2 \mathrm{~m} . \mathrm{y}$. and $3.17 \pm 0.2 \mathrm{~m} . \mathrm{y}$. were determined for rhyolite within(?) the caldera north of the map area (Clayton, 1983). The Pliocene tuff units east of the Devil's Horns rhyolite are probably part of Pdv.

Pvs

Pliocene volcaniclastic sediments, conglomerates, and tuffaceous sandstone--The unit is overlain by the Devil's Horns rhyolite (Pdv) and represents the fluvial and volcaniclastic deposits of a major drainage near the Pliocene Goat Rocks volcano.

Tsp

Saddle Mountains Basalt, Pomona Member (middle Miocene)-Darkgray to blue-black, fine-grained, abundantly to slightly plagioclase phyric olivine flood basalt. Surfaces weather to light brownish gray to light olive gray. The basalt was erupted from vents and $f$ issures in southeast. Washington, nor thern Oregon, and western Idaho, as a single sheet flow and intracanyon flow 5$50 \mathrm{~m}$ thick. Colonnade and entabulature are generally well developed. Within the map area, it occupies a paleochannel at least $120 \mathrm{~m}$ deep, representing the ancestral Columbia River (?) (Bentley and others, 1980). The basalt has reversed remanent magnetic polarity (Choinier and Swanson, 1979) and has been K-Ar dated at $12 \mathrm{~m} . \mathrm{y}$. outside of the map area (Mckee and others, 1977 ). 
Wanapum Basalt, Frenchman Springs Member (middle Miocene)--Gray to black, medium to coarse grained, very sparsely to highly plagioclase phyric flood basalt. The rock weathers to light brown or yellowish-gray and brown. In the map area, the Frenchman Springs consists of 3 to 5 individually distinguishable flows, based on phenocryst distribution and geochemistry (Anderson, written commun., 1985). The upper flow is generally aphyric, but has rare plagioclase phenocrysts up to $1.5 \mathrm{~cm}$ long and irregularly columnar to vertically platy jointing. The middle flow is aphyric to phyric, $60 \mathrm{~m}$ thick, and well-developed blocky to platy lower colonnade and vertically platy center, and contains rare to abundant plagioclase clusters up to $2.5 \mathrm{~cm}$ across. The lower sequence of flows is phyric, containing abundant phenocrysts and glomerocrysts of plagioclase $1-1.5 \mathrm{~cm}$ across, and has a collective thickness of up to $60 \mathrm{~m}$. The lowest flow has well developed colonnade and entabulature and is locally pillowed at its base. Blocky to platy columnar jointing characterizes the "upper" flows. The Frenchman Springs flows have normal magnetic polarity. They overlie Grande Ronde Basalt (15.6-16.5 m.y.) and are overlain by the Roza and Priest Rapids Members ( 14.5 m.y.) of the Wanapum Basalt south and east of the map area. Tuffaceous sediments below the Frenchman Springs (the Vantage Member of the Ellensburg Formation) are dated at 15.6 m.y. outside of the map area.

$\mathrm{Tg} \mathbf{r}$

Grande Ronde Basalt (middle Miocene)--Dark-gray to black, aphyric to very sparsely plagioclase phyric, flood basalts, comprising the thickest, most voluminous formation of the Columbia River Basalt Group. The rocks weather to light brown and pale yellowish brown. The flows are generally fine grained and not petrographically distinctive. The chemical composition varies within a broad field referred to as the Grande Ronde chemical type. This chemical composition categorizes the rock as a basaltic andesite by many classification systems. Age dates on these flows and tuffaceous sediments between the Grande Ronde and overlying Frenchman Springs Member of the Wanapum Basalt (Vantage Member of the Ellensburg Formation) restrict the age to be 15.6$16.5 \mathrm{~m} . \mathrm{y}$. The Grande Ronde flows can be divided into 4 magnetostratigraphic units, two of which occur within the map area:

$T g n_{2}-$-Upper flows with normal magnetic polarity occurring over the southeast two-thirds of the map.

Tgr $\mathbf{r}_{2}$-Upper flows with reversed magnetic polarity, underlying most, if not all of the $\mathrm{Tgn}_{2}$. 
$\operatorname{Tra}_{4}$

Middle Miocene andesite flows--A poorly studied volcanic pile above Eagle Creek Formation at Hungry Mountain. The unit is dominantly andesite and basaltic andesite flows, possibly a late continuetion of "Council Bluff" volcanism (see volcanic rocks of Council Bluff, Tcb).

Tec

Eagle Creek Formation (lower Miocene)--Interstratified lightbrown to gray conglomerate, debris flow breccia-conglomerate, pebbly volcaniclastic sandstone, tuffaceous sandstone and siltstone, and minor airfall tuff (Wise, 1961; Hammond, 1980). The unit was deposited in a predominantly fluvial sedimentary environment draining a volcanic terrain, and includes deposits from floods, mudflows, debris flows, and moderate to low energy stream systems. Boulder and cobble conglomerate cons ists of abundant well rounded dark colored porphyritic andesite clasts up to $2 \mathrm{~m}$ in diameter, in a matrix of clay, typically white montmorillonite, and forms 2-3 m-thick channel fills cut into finer gravel conglomerate and sandstone. The brecciaconglomerate forms single beds up to $3.5 \mathrm{~m} \mathrm{thick} \mathrm{that} \mathrm{lack}$ internal structure, are very poorly sorted, and contain angular to subrounded boulders and cobbles in a matrix of white to buff clay and pumice fragments. The sandstones are thin bedded, well sorted, and form lensoidal deposits up to $4 \mathrm{~m}$ thick. The Eagle Creek rests unconformably on late Oligocene volcaniclastic rocks and is unconformably overlain by middle Miocene Grande Ronde Basalt and Queternary basalt flows.

$\mathrm{Tcb}$

Volcanic rocks of Council Bluff (lower Miocene)-Dark-brown to black, interstratified, porphyritic, hypersthene-clinopyroxene andesite and basaltic andesite flows and flow breccia and minor volcaniclastic rock. The unit was called lava flows of Council Bluff by Hammond $(1980)$ and included the Council Bluff unit of Harle (1974). The unit is a flow dominated volcanic pile, ranging in age from about $26 \mathrm{~m} . \mathrm{y}$. to about $17 \mathrm{~m} . \mathrm{y}$. The flows are chiefly platy jointed, a few meters to several tens of meters thick, and have a cumulative thickness of up to $800 \mathrm{~m}$. The volcaniclastic rocks include laharic breccias, tuffs, and pyroclastic debris flow units. West of McClellan Meadow, a glomeroporphyritic hypersthene-clinopyroxene basaltic andesite gave a whole-rock K-Ar age date of $19.9 \pm 0.4 \cdot \mathrm{m} . \mathrm{y}$. (Phillips and others, 1986; sample no. 20 of Table 1). Northwest of Table Mountain, a porphyritic two-pyroxene andesite gave a whole-rock $\mathrm{K}$-Ar age date of $25.5 \pm 0.4 \mathrm{~m} . \mathrm{y}$. (Phillips and others, 1986 ; sample no. 24 of Table 1). An andesite flow south of Quartz Creek Butte, was dated to be $25.1 \pm 0.5$ and $26.5 \pm 0.7 \mathrm{m.y}$. (Laursen and Hammond, 1979; and sample no. 26 of Table 1)., age dates of $76.7 \pm 5.3$ and $77.2 \pm 5.0 \mathrm{~m} . \mathrm{y}$. were determined for 
plagioclase separates for a flow at House Rock (Laursen and Hammond, 1979; and sample no, 28 of Table 1), but this age is in obvious error.

$\operatorname{Tvd}_{3}$

Lower Miocéne dacite flows--Light-to dark-gray, porphyritic, hornblende dacite, hornblende-pyroxene dacite, clinopyroxene dacite, and hornblende pyroxene andesite flows and flow breccia. The unit is below, above, and laterally correlative with parts of the volcanic rocks of Council Bluff (Tcb). The flows are interbedded with pyroclastic flows ( $\mathrm{Tvt}_{3}$ ), andesite flows (Tva ${ }_{3}$ ), and basaltic andesite flows $\left(T^{2} b_{3}\right)$. Northeast of Iron Creek Butte, a black, glassy dacite flow caps a ridge underlain by tuff dated at about 18-19 m.y. (see Tvt 3 ). The flow is about $10 \mathrm{~m}$ thick, columnar jointed, with a vesicular flow top. The dacite is porphyritic to glomeroporphyritic, with phenocrysts of plagioclase and augite in a very fine grained hypocrystalline groundmass of plagioclase microlites, clinopyroxene, and abundant brown glass. The color and visible mineralogy suggest basalt, but the chemical analyses reveal silica values of 64-68 percent for this flow and similar flows at Bluff Mountain, Cispus Camp, and northwest and south of Tongue Mountain. The flow near Iron Creek Butte has a $\mathrm{K}-\mathrm{Ar}$ whole-rock age date of $15.6 \pm 0.2 \mathrm{~m} . \mathrm{y}$. (Phillips and others, 1986, and sample no. 17 of Table 1).

$\operatorname{Tvt}_{3}$

Lower Miocene tuffs and tuff breccia--Light-gray to brown dacitic to rhyodacitic tuff, tuff breccia, and interbedded volcaniclastic sandstone with minor laharic breccia and conglomerate. At East Canyon Creek, a well bedded sequence of pyroclastic flows and volcaniclastic sediments forms a section $300 \mathrm{~m}$ thick (Harle, 1974). The pyroclastic flows are 3 to $12 \mathrm{~m}$ thick, light colored, poorly welded to nonwelded, with abundant pumice, euhedral plagioclase crystals, minor subhedral pyroxene(?), and small (2 $\mathrm{mm}$ ) sanidine crystals in a matrix of pumice fragments. The lithic fragments range from 10-30 percent. The East Canyon Creek section was K-Ar dated at $19.4 \pm 1.0$ and $20.0 \pm 1.0 \mathrm{~m}$.y. us ing plagioclase separates (Hammond, 1980 , and sample no. 21 of Table $1)$, but this date conflicts with the whole-rock K-Ar age of 25.5 $\pm 0.4 \mathrm{m.y}$. (Phillips and others, 1986 , and sample no. 24 of Table 1) for a flow stratigraphically above the tuff at Table Mountain, part of the volcanic rocks of Council Bluff. The tuff unit may be upper oligocene in age. Elsewhere, the tuffs range from vitric tuffs to lithic-pumice-crystal tuffs, welded to unwelded, and quartz bearing to lacking quartz. Between Iron Creek and Yellowjacket Creek, tuffs form thin to very thick interbeds between andesite and dacite flows. A tuff at Greenhorn Buttes, stratigraphically high in the section, gave K-Ar age dates of $18.4 \pm 0.3$ and $18.9 \pm 0.3 \mathrm{~m} . \mathrm{y}$. for a plagioclase separate (Hammond, 1980, and sample no. 19, Table 1). It is overlain by a glassy dacite flow dated at $15.6 \pm 0.2 \mathrm{~m} . \mathrm{y}$. (Phillips and others, 
1986 , and sample no. 17 of Table 1 ).

$\operatorname{Tvr}_{3}$

Lower Miocene rhyolite flows--Poorly studied outcrops of lightcolored rhyolite south of the Cispus River near Squaw Creek. The unit is probably related to the rhyolite intrusions $1 \mathrm{~km}$ northwest of the outcrops and at Spud Hill. (See Tir)

TVa 3

Tvbä 3

Lower Miocene andesite and basaltic andesite flows--Light- to dark-gray, porphyritic, hypersthene andesite, hornblende andesite, hypersthene basaltic andesite, and two-pyroxene basaltic andesite flows and flow breccia. At Lone Tree Mountain, the flows are microphyric to porphyritic, with phenocrysts of plagioclase, augite, and minor hypersthene in either a glassy or holocrystalline granular groundmass. A whole-rock K-Ar age date of $22.1 \pm 1.3 \mathrm{~m} . \mathrm{y}$. was determined for a flow at Lone Tree Mountain (Phillips and others, 1983; and sample no. 22 of Table 1). Between Iron Creek and Yellowjacket Creek, lower Miocene andesites and basaltic andesites are interlayered with tuffs, tuff breccias, and dacite flows. This volcanic pile is similar to the lithologies which make up much of the volcanic rocks of Council Bluff (Tcb) and is a probable correlative. Near the Klickton Divide, the basaltic andesite is poorly studied, but it has been described as being similar to the Fifes Peak Formation north of the map area (Don Swanson, oral commun., 1985). The queried units south of the Klickitat River may be of late oligocene age; currently there is no age control.

$\mathrm{Tvb}_{3}$

Lower Miocene basalt flows-Dark-gray, aphyric to porphyritic, clinopyroxene basalt flows at Huffaker Mountain. The unit is similar in appearance to most of the lower Miocene basaltic andesite flows (Tvba ${ }_{3}$ ), but chemical analyses reveal a slightly less silicic composition $(49-53 \%$ sio, 2$)$. The basalt flows and associated flow breccia form a broad shield volcano, centered just south of the top of Huffaker Mountain. An age date reported for this unit by Russ Evarts and Roger Ashley (written commun., 1986 ) is $23.2 \pm 0.70 \mathrm{~m} . \mathrm{y}$. for a plagioclase separate (sample no. 23 of Table 1 ).

$\mathrm{Trc}_{3}$

Lower Miocene volcaniclastic rocks--Multicolored volcaniclastic rocks including tuff, tuff breccias, lithic breccia, conglomerate, and volcaniclastic sandstone are interbedded with lava flows, shown separately as $\mathrm{Tva}_{3}, \mathrm{Tvba}_{3}$, and $\mathrm{Tvd}_{3}$ where unit 
extent and available mapping permitted, and shown as $\mathrm{Tvt}_{3}$ where the unit is primarily unreworked tuff and tuff breccia. The unit is similar to Tre, and Toh (Ohanapecosh Formation), but is commonly thinner, less altered, and especially less zeolitized and is stratigraphically bounded by units younger than the Oligocene volcaniclastic rocks. The volcaniclastic sandstone consists of fine-grained, generally well sorted and bedded, lithified sediments consisting of rounded andesite and altered pumice particles in a matrix of altered glass, clay, broken crystals, and organic material. The sediments are the result of fluvial reworking and deposition of volcaniclastic material from the surrounding terrain. Thin interbeds of airfall tuff suggest quiet water deposition for some sandstones, including possible lacustrine facies.

$\mathrm{Tvba}_{2}$

Upper Oligocene basaltic andesite flows--Gray, porphyritic to glomeroporphyritic, pyroxene basaltic andesite and minor andesite and flow breccia associated with these flows. The andesite weathers tan and brown. The rocks have phenocrysts of plagioclase, augite, and/or hypersthene with a groundmass of plagioclase, clinopyroxene, opaque minerals, and glass. The groundmass is typically altered to chlorite, clays, and zeolites. The unit is queried (Tvba ${ }_{2}$ ?) where flows may be as young as early Miocene. A whole-rock K-Ar age date for a flow on Bishop Mountain was determined to be $30.1 \pm 2.2 \mathrm{m.y}$. (Phillips and others, 1986 ; sample no. 27 of Table 1 ).

$\mathrm{Trc}_{2}$

Upper Oligocene volcaniclastic rocks--Rocks very similar to those of the Ohanapecosh Formation (Toh) but not called Ohanapecosh because they occur at great distances from the type section and are separated from it by major river valleys and/or structures (see the description for Toh). Where queried, the unit may be younger, possibly of early Miocene age.

Toh

Ohanapecosh Formation (Oligocene)--Greenish to brown and maroon dacitic to basaltic-andesitic lithic breccia, tuff, and tuff breceia, and volcaniclastic siltstone, sandstone, and conglomerate (Fiske and others, 1963; Winters, 1984; Vance and others, in press). The breccias are typically unstratified, crudely graded, or very thickly bedded and poorly sorted, with clasts of heterolithologic debris, including highly altered pyroclastic rock, porphyritic basaltic andesite to dacite, and aphyric to glassy lave in a matrix of altered plagioclase, devitrified glass shards, and clay. Sandstone and ash to lapilli tuff commonly form well bedded, graded, parallel laminated sequences. Most of the unit is extensively zeolitized and locally 
hydrothermally altered. Within the map area, the Ohanapecosh has an approximate thickness of $5,000 \mathrm{~m}$. The base of the formation is exposed at Johnson Creek, where it interfingers with the micaceous feldspathic sandstone beds of Chambers Creek (Winters, 1984). The Johnson Creek section is characterized by medium- to very coarse grained volcanic arenite, volcanic siltstone and mudstone, lapilli-tuff, tuff, conglomerate, and breccia, and there is a complete absence of lava flows. South of the Cispus River, along East Canyon Ridge, the unit is 70 percent primary pyroclastic deposits (tuff and tuff breccia) and 30 percent first-cycle reworked pyroclastic material (Nimz, 1983). The reworked sediment forms beds a few centimeters thick to more than $10 \mathrm{~m} \mathrm{thick,} \mathrm{with} \mathrm{some} \mathrm{grading,} \mathrm{poor} \mathrm{to} \mathrm{moderate} \mathrm{sorting,} \mathrm{and} \mathrm{an}$ abundance of subangular clasts. The pyroclastic deposits are 1$18 \mathrm{~m} \mathrm{thick}$, average about $3 \mathrm{~m} \mathrm{thick}$, and include both welded and nonwelded tuffs and tuff breccia. No lava flows are present in the East Canyon Ridge section. At Bishop Mountain, basaltic andesite and andesite lava flows are more prevalent. These flows are interbedded with Ohanapecosh volcaniclastic rocks, and while they technically could be considered part of the formation, they are shown separately as Trbag. This is stratigraphically high in the formation, and most of the volcaniclastic rocks are primarily pyroclastic material. A basaltic andesite flow on the northeast side of Bishop Mountain was whole-rock K-Ar dated at $30.1 \pm 2.2$ m.y. (Phillips and others, 1986; and sample no. 27 of Table 1 ). Within the map area, the Ohanapecosh can be shown to span the Oligocene and possibly include some upper Eocene strata (see the description of Tcc, beds of Chambers Creek, for older age control). This is in agreement with the dating of this formation north of the map area (Vance and others, in press).

Tv

Tertiary volcanic units, undivided (Oligocene to Miocene)-Volcanic rocks in the upper drainage of the Cispus and Klickitat Rivers. The rocks include lower to upper Oligocene volcaniclastic rocks (Ohanapecosh Formation), Oligocene basaltic andesite flows, and lower. Miocene lava flows with interbedded volcaniclastic rocks (correlative with the Fifes Peak Formation and volcanic rocks of Council Bluff).

Tec

Chambers Creek beds (middle to late Eocene)--Light-gray micaceous feldspathic sandstone and lithic feldspathic sandstone, and darkgray mudstone and siltstone with sparse intercalations of coal, lapilli tuff, tuff, and tuffaceous sedimentary rock (Winters, 1984). The beds are primarily channel bar, sidestream, and lake deposits from a river system that flowed west and southwest across a low-lying alluvial plain. About half of the exposed unit is mudstone, with locally abundant small iron-oxide-cemented concretions and less common coal partings, altered vitric tuff claystone, and graded beds of lapilli tuff and coarse volcanic 
sandstone. The feldspathic and lithic feldspathic sandstones are very fine to fine grained, parallel laminated to small ripple bedded, and contain carbonaceous laminae, carbonized wood fragments, leaf imprints, carbonate-cemented concretions, and less common burrows and root scars. Paleocurrent directions and sandstone mineralogy indicate an eastern provenance dominated by plutonic and high-grade metamorphic rocks. The total thickness of the sedimentary sequence is more than $1,150 \mathrm{~m}$, and the base is not exposed. The upper beds are interstratified with and overlain by andesitic volcanic sandstones and coarser volcaniclastic rocks of the late Eocene to early Oligocene Ohanapecosh Formation. Both the Chambers Creek beds and the Ohanapecosh Formation at Johnson Creek have been folded into a northwest-trending, northwest-plunging faulted anticline and cut by abundant shallow intrusions of basaltic andesite, andesite, and diorite porphyry. A floral assemblage from a tuffaceous mudstone from the stratigraphically lowest part of the unit contains a tree fern restricted to the lower Puget Group, spanning the Franklinian through lower Ravenian floral zones of Wolfe (1981), of primarily middle Eocene age. A fission-track date of $35.9 \pm 0.7 \mathrm{~m} . \mathrm{y}$. on $\mathrm{zircon}$ from an altered vitric tuff clay is thought to be reset (Winters, 1984).

\section{Tertiary Intrusiye Rocks}

\section{$\mathrm{Ti}$}

Tertiary intrusive rocks, undifferentiated--sills, dikes, plugs, and stocks of undetermined compositions and uncertain age.

Tia

Intrusive andesite (upper Oligocene to Pliocene)--Includes darkto light-gray, aphanitic to porphyritic, pyroxene basaltic andesite, pyroxene andesite, and hornblende andesite. The rocks are generally partially altered to calcite and clays. Most of the intrusions are of Miocene age.

\section{Tib/Tiba}

Intrusive basalt and/or intrusive basaltic andesite (upper Oligocene to Pliocene)--Includes dark-gray aphyric and phyric augite basalt and basaltic andesite dikes. (The unit is mapped as Tiba where chemical data were available to classify the rocks.) Most of the intrusions are of Miocene age. 


\section{Tid}

Intrusive dacite (lower Miocene to Pliocene)--Gray, porphyritic, hornblende and pyroxene dacite sills, dikes, plugs, and stocks. At Sunrise Peak the rock is a light-green dacite porphyry with phenocrysts of subhedral to euhedral plagioclase, clear anhedral to subhedral quart]o, subhedral hornblende, and minor pyroxenes and orthoclase in a very fine grained chloritized groundmass. Northwest of Jumbo Peak, the rock is a greenish gray porphyry with phenocrysts of euhedral plagioclase altering to sericite, and euhedral to subhedral hornblende in a fine-grained holocrystalline groundmass. East of Jumbo Peak, a dark-gray dacite porphyry consists of phenocrysts of plagioclase altering to sericite and calcite, and clinopyroxene in a cryptocrystalline matrix (Nimz, 1983).

Tir

Intrusive rhyolite (Miocene)--Light-gray to cream-colored to white, very fine grained rhyolite. In thin section, the rock is holocrystalline microporphyritic, with clear subhedral and anhedral quartz, plagioclase, $\mathrm{K}$-feldspar, and mica. The rock has a very high silica content $\left(>77 \% \mathrm{SiO}_{2}\right)$ (sample MK85-6-22 of Table 2) and is quite anomalous compared to the bulk of Tertiary. Cascade volcanism.

\section{Tidi}

Diorite intrusions (Miocene)--Fine- to medium-grained, commonly porphyritic, pyroxene diorite, pyroxene-hornblende diorite, and hornblende diorite forming sills and stocks.

\section{Tigb}

Gabbro intrusions (upper Oligocene to Pliocene)--A coarsegrained, porphyritic pyroxene gabbro forms a sill on the south side of the North Fork of the Cispus River; it may be continuous with a sill mapped just north of the $r$ iver as Tib. A dark-gray pyroxene gabbro forms a small stock east of Badger Peak.

\section{Tiqd}

Quartz diorite intrusions (Miocene)--Light-gray, fine- to mediumgrained, equigranular to porphyritic, hornblende quartz diorite and hypersthene-hornblende quartz diorite. At McCoy Creek, a porphyritic to equigranular biotite-hornblende quartz diorite stock has been altered and hosts a low-grade porphyry coppermolybdenum deposit and a few gold-bearing veins (Link, 1985). Where least altered, the McCoy Creek intrusion consists of phenocrysts of plagioclase (Ansg to $A_{25}$ for zoned crystals), hornblende, quartz, pyroxene, and altered mafic clots, probably 
of biotite. The groundmass had an original composition similar to the phenocryst minerals, but it has been altered to quartz, sericite, calcite, and epidote. A K-Ar age date from the sericite is $24.0 \pm 0.9 \mathrm{~m} . \mathrm{y}$. (Armstrong and others, 1976; and sample no. 25 of Table 1 ). 


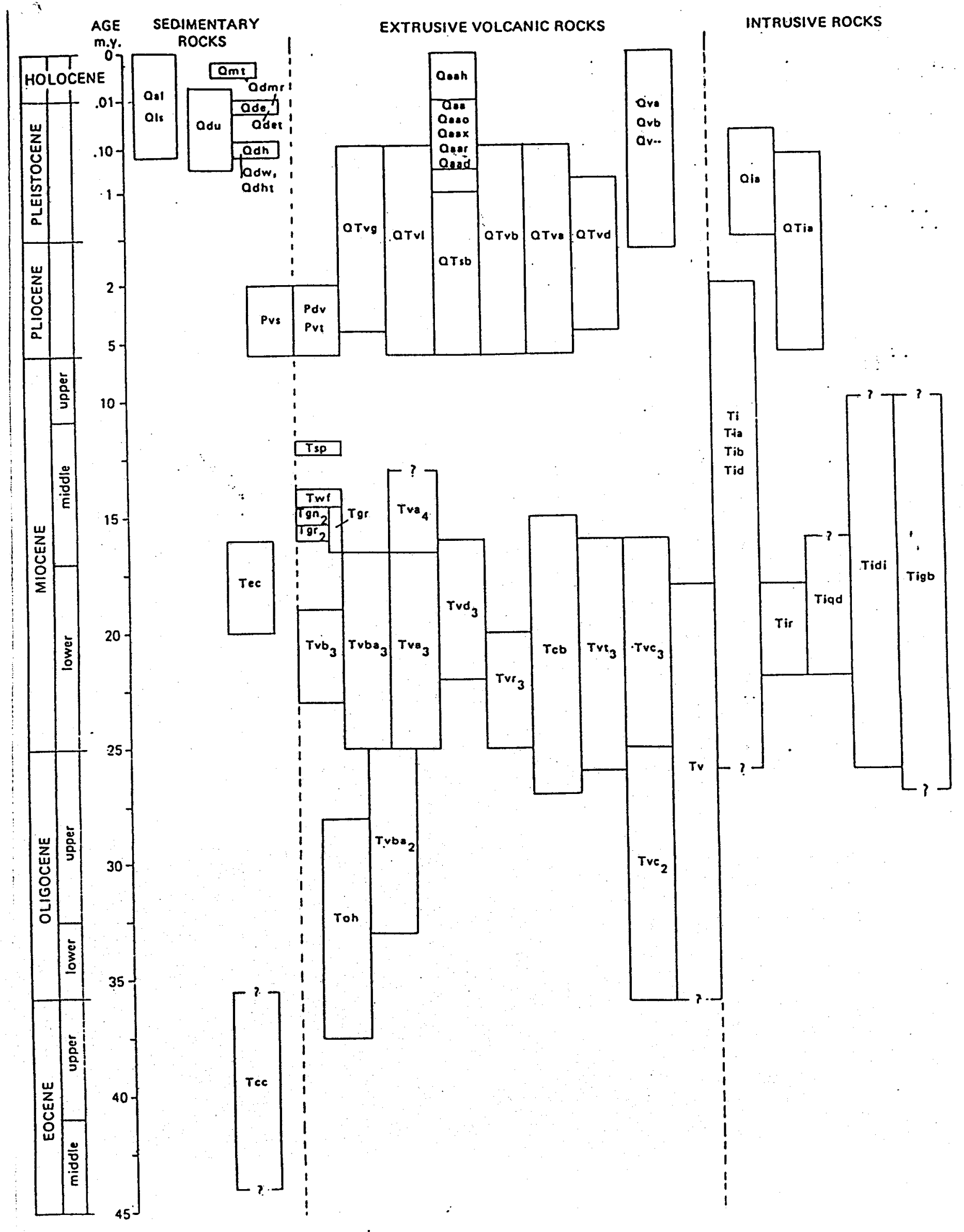

Figure 1. Correlation-Duration Diagram - Mount Adams Quadrangle 
TABLE 1. AGE OATES FOR THE HOUNT AOAKS 1:100,000 OUAORAMGLE

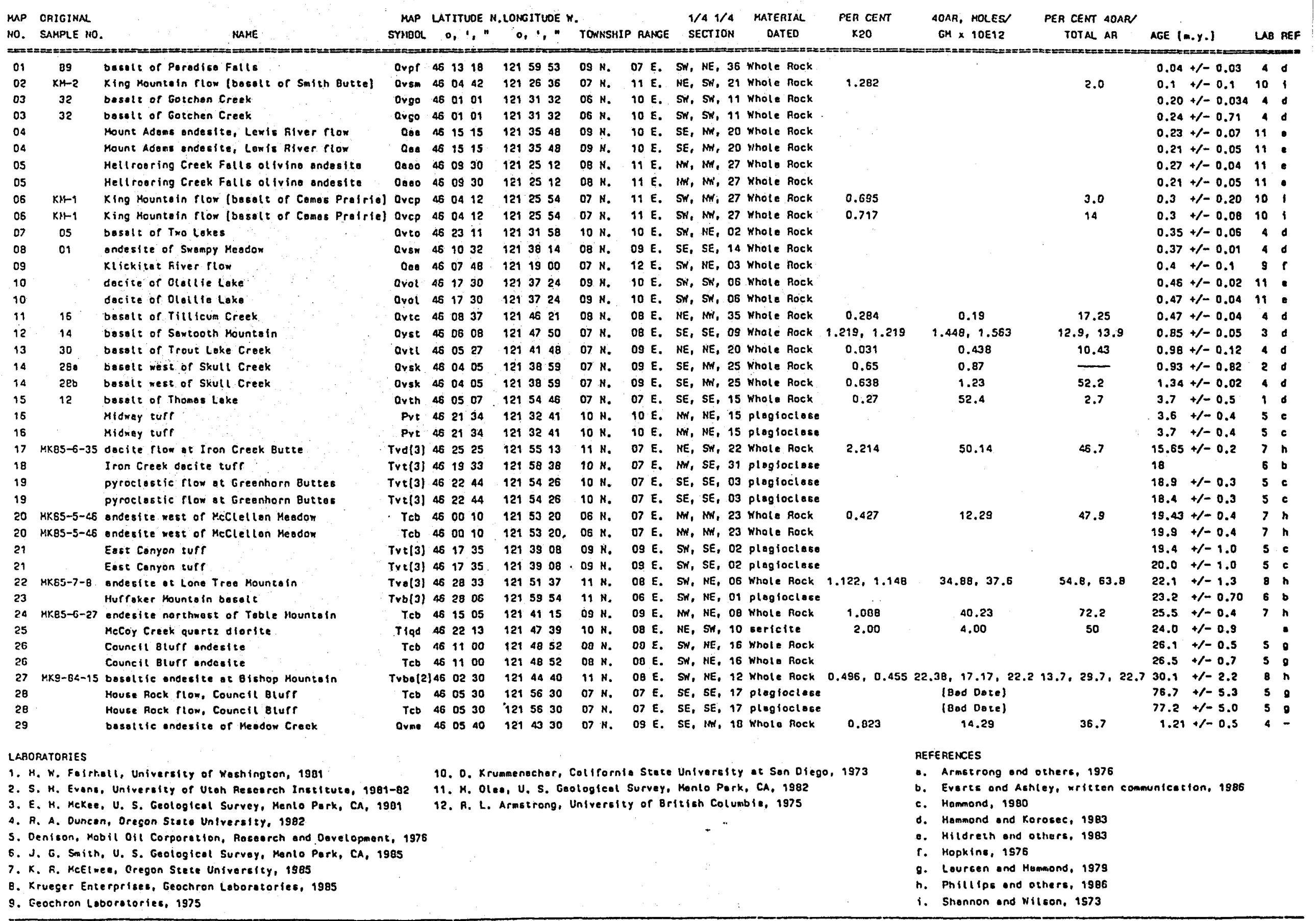


Table 2. Major element analyses for igneous rocks of the Mount Adams Quadrangle.

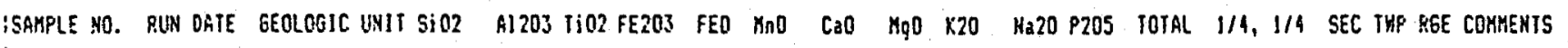

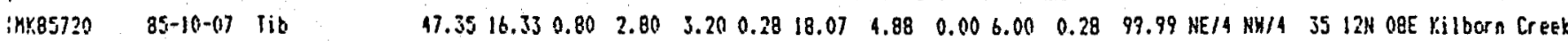

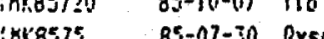

Bs- $81-30$ Orsc

Mir:98431 84-12-017 levse

ixypa112 34-12-07 Ovse

ixl:98429 84-12-07 liqb

iml:93420 85-03-25 liob

iki:8565, $85-07-30$ Trbi3)

:4x.85721 85-10-07 TYba(3)

ikK:8562 BS-07-30 Tro(3)

ikr.8569 85-07-30 ivba(3)

ink85631 $85-07-30 \quad$ Trba $(3)$

i4x.98111 85-03-25 Tib

ikx:856?1 85-87-30 Trba(3)

ink85620 85-01-50 Troa(3)

ikiristi 85-07-30 Trba (3)

imxes915 87-03-29 evod

imp $98415 \quad 84-12-07$ Irbal2)

im:10844 84-12-07 Tia

in:98426 84-12-197 Tiba

Ixx93422 : $84-12-07$ Trbal21

ikK3598 87-03-29 erba

inK.95910 B7-03-29 Trba(3)

inK8599 87-03-29 Orbo

97-113-29. Trba(3)

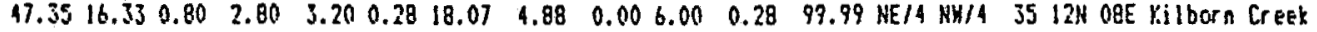

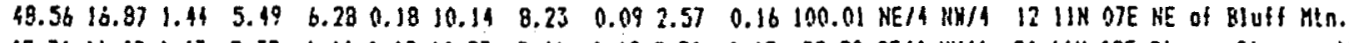

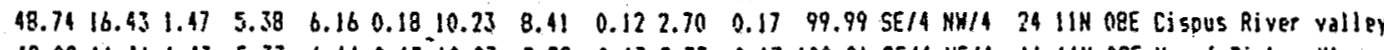

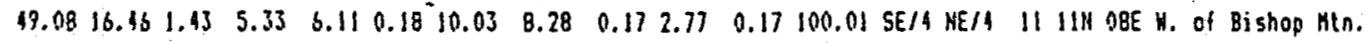

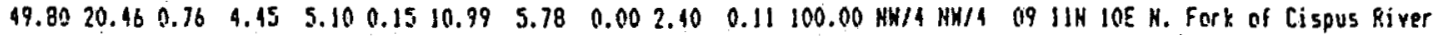

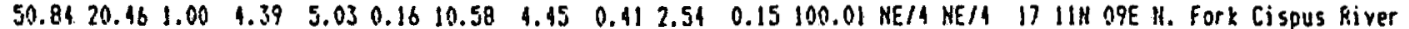

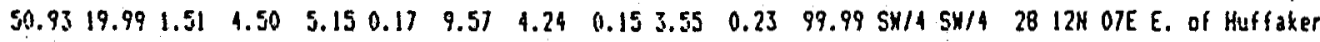

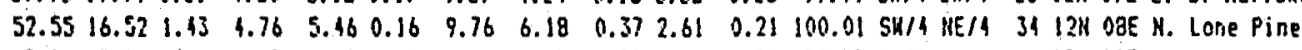

53.04 $18.48 \quad 1.21 \quad 4.35 \quad 4.990 .15 \quad 9.32 \quad 4.87 \quad 0.592 .78 \quad 0.21 \quad 99.99$ SW/4 SW/4 36 12W O6E Hutíaker Htn.

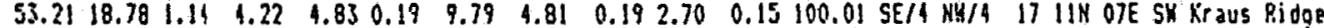

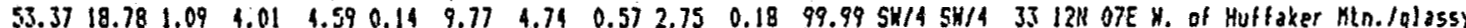

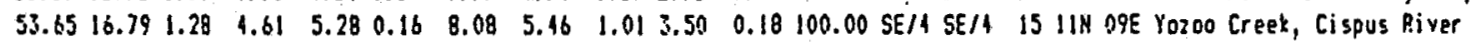

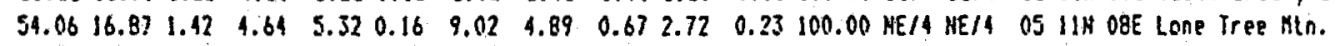

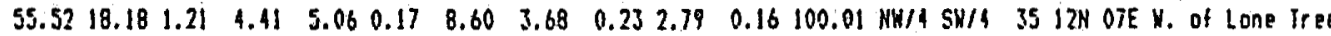

$55.68 \quad 18.00 \quad 1.22 \quad 4.38 \quad 5.02 \quad 0.16 \quad 8.51 \quad 3.56 \quad 0.28 \quad 3.02 \quad 0.16 \quad 99.99$ NE/4 NW/4 09 IIM D7E N. side oi Yraus Ridge

$56.02 \quad 17.01 \quad 1.11 \quad 7.54 \quad--0.12 \quad 7.52 \quad 4.61 \quad 1.434 .01 \quad 0.43 \quad 99.80$ 5W/4 SE/4 18 10.4 08E Lower flow at Pinto Creek

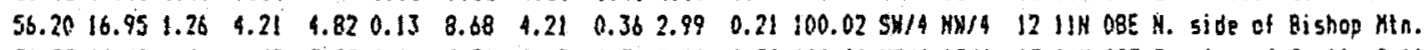

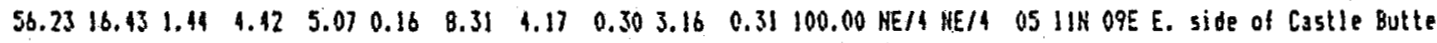

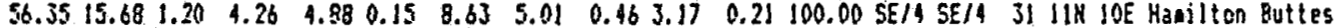

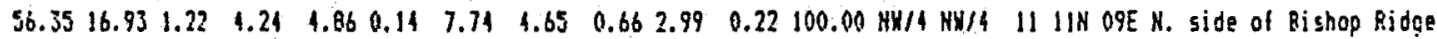

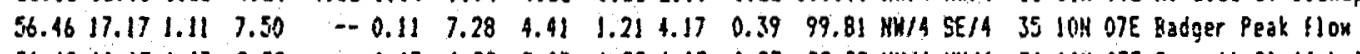

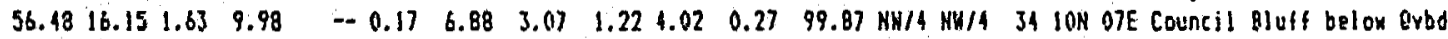

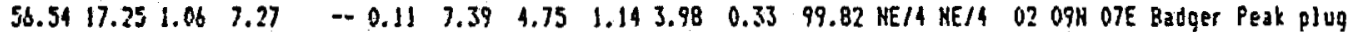

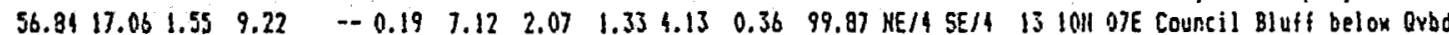

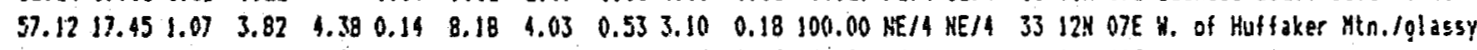

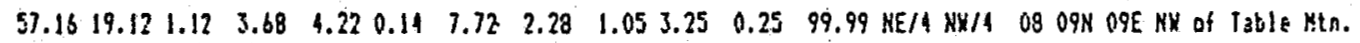

$B 2-07-30$ Teb

$85-07-30$ TYba(3)

$\begin{array}{lll}\text { ink.98416 } & 84-12-07 \quad \text { Trba (2) } \\ \text { ikt85636 } & 85-07-30 \text { Tra }(3)\end{array}$

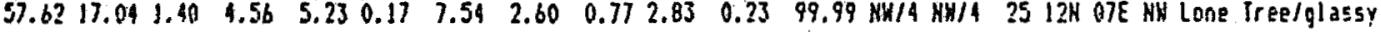

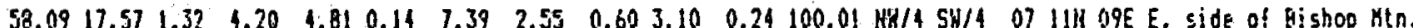

(k) $98410 \quad 81-12-07$ Tis

inrs5638 85-07-30 [ya(3)

ikr.8579: 85-07-30 ITral31)

iMX858!

$85-10-07$ Jia

94-12-07 Tia

$85-07-30$ Ivo(3)

$84-12-07 \quad(1 \mathrm{id})$

85-10-07 (TV:13)1

(K):98417

$84-12-(i 7)(1 i d i)$

$84-12-0) \quad(7 i 0)$

$85-03-25$ IIjidj

$\begin{array}{lll}\text { ink:98413A } & 85-03-25 \text { Tid } \\ \text { iMk:85635 } & 85-03-30 \text { TyJ(3) }\end{array}$

$\begin{array}{lll}\text { MM1:85635 } & 85-07-30 & \text { Tys(3) } \\ \text { ink:8574 } & 85-10-07 & \text { Tyd(3) }\end{array}$

:47:85623 $85-07-30$ Tid

iYK.8562? 85-07-30 Jir

$58.2817 .07 \quad 1.12 \quad 3.71 \quad 1.24 \quad 0.15 \quad 7.48 \quad 3.56 \quad 1.212 .79 \quad 0.20100 .01$ 5E/4 SE/4 29 I!N 07E bron Creek Butte

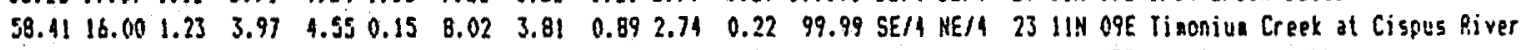

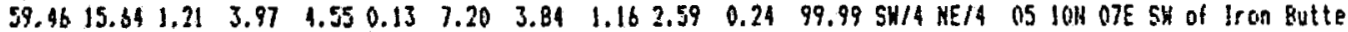

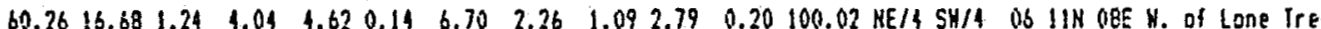

$61.5316 .611 .11 \quad 3.50 \quad 4.01 \quad 0.13 \quad 3.78 \quad 3.06 \quad 1.71 \quad 4.28 \quad 0.28 \quad 100.00 \mathrm{NW} / 4$ NW/4 24 11H OBE SW Bishop Mtn.

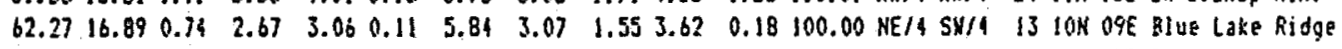

$63.94 \quad 15.910 .88 \quad 3.55 \quad 1.07 \quad 0.14 \quad 5.27 \quad 1.69 \quad 1.552 .92 \quad 0.19 \quad 100.01 \mathrm{~N} / 2$ WH/4 16 11N OBE E. of Cispus Canp

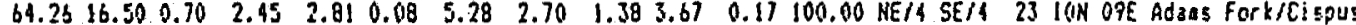

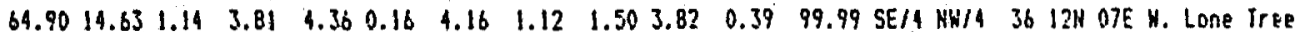

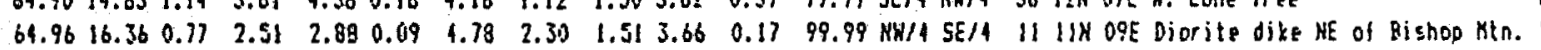

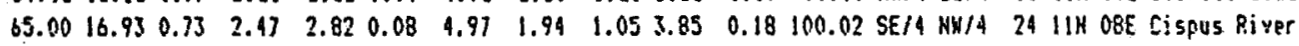

$65.6116 .930 .70 \quad 2.11 \quad 2.770 .08 \quad 5.05 \quad 1.84 \quad 1.003 .12 \quad 0.17 \quad 99.98$ WW/4 WW/4 30 III Q9E Cispus River valley

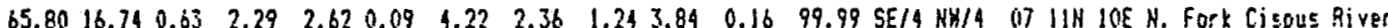

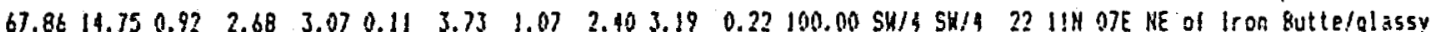

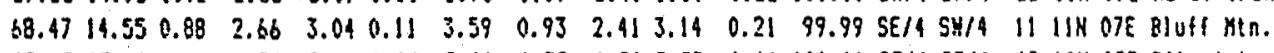

$69.1915 .110 .6 ? \quad 2.30 \quad 2.640 .14 \quad 3.00 \quad 0.72 \quad 1.903 .93 \quad 0.16 \quad 100.01$ SE/4 SE/4 19 10N O9E dike ints Spus Hill

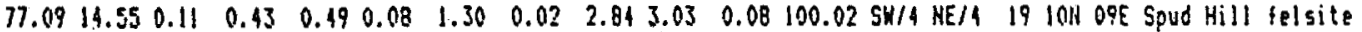

Analyses by XRF, Department of Geology, Washington state University. All analyses are normalized on

a volatile free basis with the oxidation state of

iron set at the arbitrary ratio of $\mathrm{Fe}_{2} \mathrm{O}_{3} / \mathrm{FeO}=0.87$.
When the geologic unit for a sample is shown within parentheses, it indicates that the unit is too small to show on the map. 


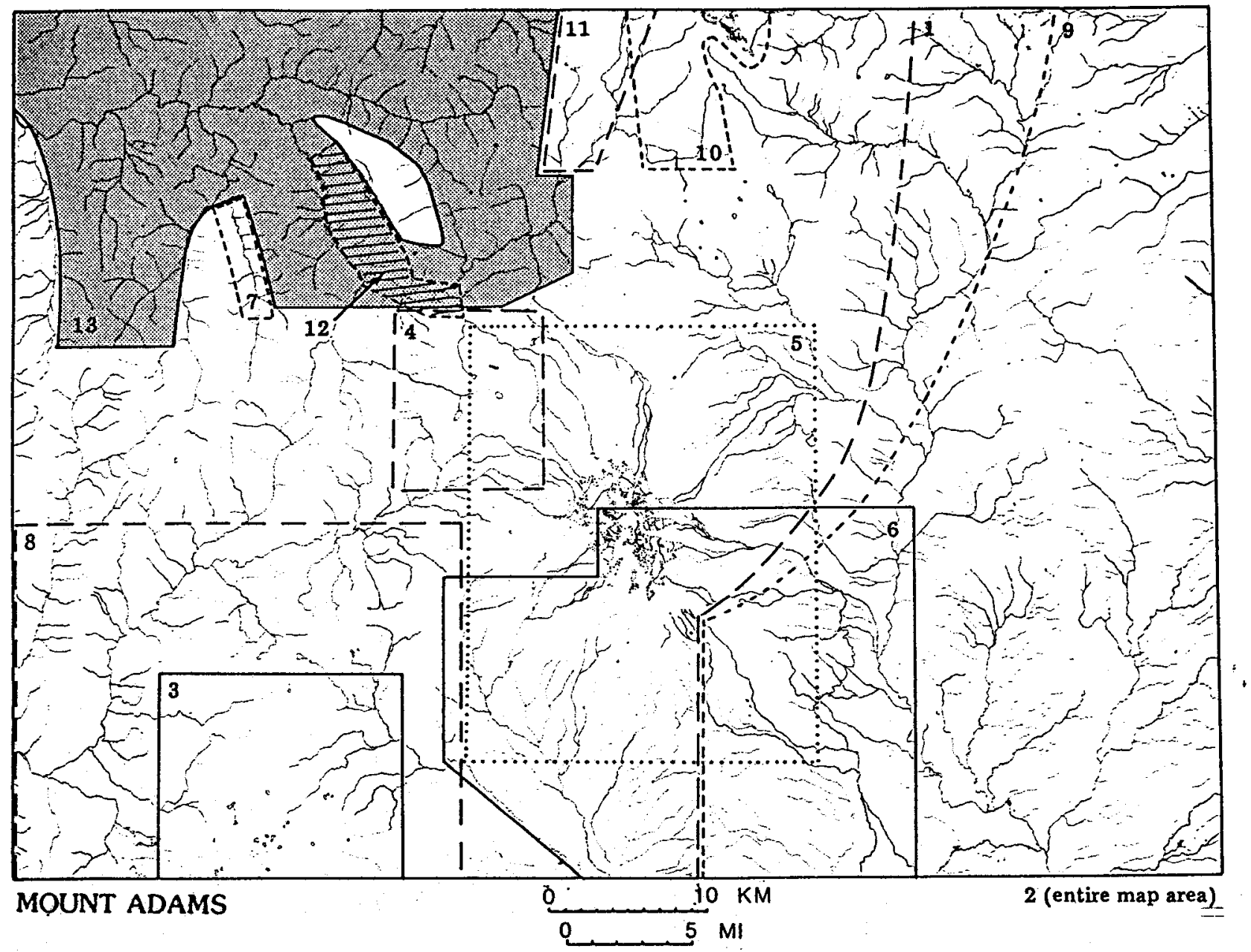

Key to Map Sources

1. Bentley and others, 1980

2. Hammond, 1980

3. Hammond, 1983

4. Harle, 1974

5. Hildreth and others, 1983

6. Hopkins, 1976

7. Link, 1985
8. Schuster and others, 1978

9. Swanson and others, 1979

10. Swanson and Clayton, 1983

11. Winters, 1984

12. 1985 reconnaissance mapping by Brent Barnett

13. 1984-1985 reconnaissance mapping by Michael Korosec

Figure 2. Source of Data Map — Mount Adams Quadrangle 


\section{References Cited}

Armstrong, R. L.; Harakal, J. E.; Hollister, V. F., 1976 , Age determination of late Cenozoic porphyry copper deposits of the North American cordillera: Institution of Mining and Metallurgy Transactions, Section B, v. 85, p. 239-244.

Bentley, R. D.; Anderson, J. L.; Campbell, N. P.; Swanson, D. A., 1980 , Stratigraphy and structure of the Yakima Indian Reservation, with emphasis on the Columbia River Basalt Group: U.S. Geological Survey Open-File Report 80-200,86 p., 1 plate, scale $1: 84,480$.

Choiniere, S. R.; Swanson, D. A., 1979 , Magnetostratigraphy and correlation of Miocene basalts of the northern Oregon coast and Columbia Plateau, southeast Washington: American Journal of Science, v. 279, no. 7, p. 755-777.

Clayton, G. A., 1983 , Geology of the White Pass area, southcentral Cascade Range, Washington: University of Washington Master of Science thesis, 212 p., 1 plate.

Fiske, R. S.; Hopson, C. A.; Waters, A. C., 1963, Geology of: Mount Rainier National Park, Washington: U.S. Geological Survey Professional Paper 444,93 p., 1 plate, scale $1: 62,500$.

Hammond, P. E., 1980 , Reconnaissance geologic map and cross sections of southern Washington Cascade Range, latitude $45^{\circ}$ $30^{\prime}-47^{\circ} 15^{\prime}$ 'N., longitude $120^{\circ} 45^{\prime}-122^{\circ} 22.5^{\prime}$ W.:

Portland State University Department of Earth Sciences, 31 p., 2 sheets, scale $1: 125,000$.

Hammond, P. E., written communication, 1983, Preliminary geologic map of the Indian Heaven area: The author, unpublished map, scale $1: 62,500$.

Hammond, P. E.; Korosec, M. A., 1983, Geochemical analyses, age dates, and flow-volume estimates for Quaternary volcanic rocks, southern Cascade Mountains, Washington: Washington Division of Geology and Earth Resources Open-File Report 8313,36 p., 1 plate.

Harle, D. S., 1974 , Geology of Babyshoe Ridge area, southern Cascades Washington: Oregon State University Master of Science thesis, 71 p., 1 plate, scale $1: 24,000$.

Hildreth, Wes; Fierstein, Judy; Miller, M. S., 1983, Mineral and geothermal resource potential of the Mount Adams wilderness and contiguous roadless areas; Skamania and Yakima Counties, Washington: U.S. Geological Survey Open-File Report 83-474, 36 p., figure 2, scale 1:100,000. 
Hopkins, K. D., 1976 , Geology of the south and east slopes of Mount Adams volcano Cascade Range, Washington: University of Washington Doctor of Philosophy thesis, 143 p., 1 plate, scale $1: 63,360$.

Laursen, J. M.; Hammond, P. E., 1979, Summary of radiometric ages of Washington rocks; Supplement 1 , July, 1972 through December, 1976: Isochron/West, no. 24, p. 3-24.

Link, J. E., 1985 , Gold and copper mineralization in the McCoy Creek district, Skamania County, Washington: Washington State University Master of Science thesis, 136 p., 4 plates, scale $1: 12,000$.

Mckee, E. H.; Swanson, D. A.; Wright, T. T., 1977, Duration and volume of Columbia River volcanism, Washington, Oregon, and Idaho [abstract]: Geological Society of America Abstracts with Programs, v. 9, no. 4, p. 463-464.

Nimz, G., 1983 , Geology of the Sunrise Peak area, south Cascade Range, Washington: University of Washington Geology Department Senior project, unpublished, 35 p.

Phillips, W. M.; Korosec, M. A.; Schasse, H. W.; Anderson, J. L.; Hagen, R. A., 1986, K-Ar ages of volcanic rocks in southwest Washington: Isochron/West.

Porter, S. C., 1976, Pleistocene glaciation in the southern part of the North Cascades Range, Washington: Geological Society of America Bulletin, v. 87, p. 61-75.

Schuster, J. E.; Blackwel1, D. D.; Hammond, P. E.; Hunt ting, M. T., 1978, Heat flow studies in the Steamboat Mountain-Lemei Rock area, Skamania County, Washington: Washington Division of Geology and Earth Resources Information Circular 62, 56 p., figure 2, scale 1:200,000.

Shannon and Wilson, 1973, Geologic studies of Columbia River basalt structures and age of deformation; the DallesUmatilla region, Washington and Oregon; Boardman nuclear project: Portland General Electric Company, $1 \mathrm{v}$.

Sheppard, R. A., 1967, Geology of the Simcoe Mountains volcanic area, Washington: Washington Division of Mines and Geology Geologic Map GM-3, 1 sheet, scale $1: 125,000$.

Swanson, D. A.; Anderson, J. L.; Bentley, R. D.; Byerly, G. R.; Canp, V. E.; Gardner, J. N.; Wright, T. L., 1979, Reconnaissance geologic map of the Columbia River Basalt Group in eastern Washington and northern Idaho: U.S. Geological Survey Open-File Report $79-1363,26$ p., 12 plates, scale $1: 250,000$. 
Swanson, D. A.; Clayton, G. A., 1983, Generalized geologic map of the Goat Rocks wilderness and roadless areas Lewis and

Yakima Counties, Washington: U.S. Geological Survey Open-

File Report 83-357,10 p., 1 plate, scale $1: 48,000$.

Travis, R. B., 1955, Classification of rocks: Colorado School of Mines Quarterly, v. 50, no. $1,98 \mathrm{p}$.

Vance, J.A.; Clayton, G. A.; Mattinson, J.M.; Naeser, C. W., in press, Early and middle Cenozoic stratigraphy of the Mount Rainier-Tieton River area, southern Washington Cascades. In Schuster, J. E., editor, in preparation, selected papers on the geology of Washington: Washington Division of Geology and Earth Resources Bulletin, figure 2, scale 1:540,000.

Wait , R. B., Jr., 1977 , Guidebook to Quaternary geology of the Columbia, Wenatchee, Peshastin, and upper Yakima Valleys, west-central Washington: U.S. Geological Survey Open-File Report 77-753, $25 \mathrm{p}$.

Winters, W. J., 1984, Stratigraphy and sedimentology of Paleogene arkosic and volcaniclastic strata, Johnson Creek-Chambers Creek area, southern Cascade Range, Washington: Portland State University Master of Science thesis, 162 p., 2 plates. Geologic map: plate 1a, scale 1:24,000.

Wise, W. S., 1961 , The geology and mineralogy of the Wind River area, Washington, and the stability relations of celadonite: Johns Hopkins University Doctor of Philosophy thesis, $2 \mathrm{v}$., 1. plate, scale 1:62,500.

Wolfe, E. W.; McKee, E. H., 1972, Sedimentary and igneous rocks of the Grays River quadrangle, Washington: U.S. Geological Survey Bulletin $1335,70 \mathrm{p}$.

Zanettin, Bruno, 1984 , Proposed new chemical classification of volcanic rocks: Episodes, v. 7, no. 4, p. 19-20. 


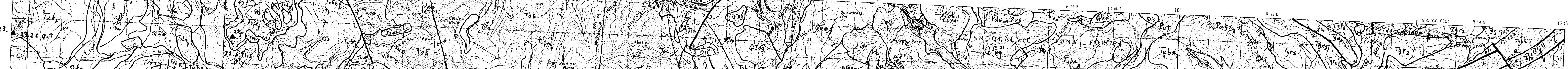

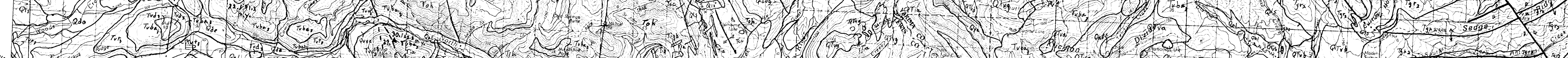

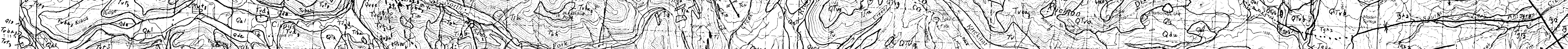

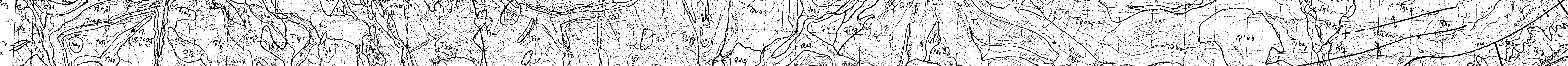

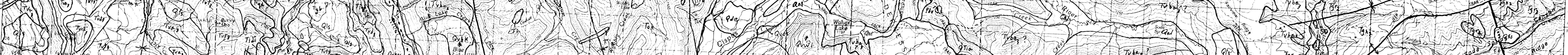
H. 1.

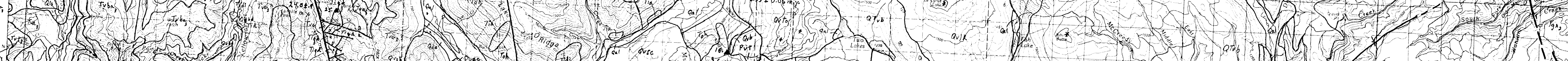


-



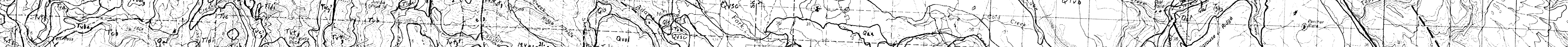
(3). (3) (I) N N 20.

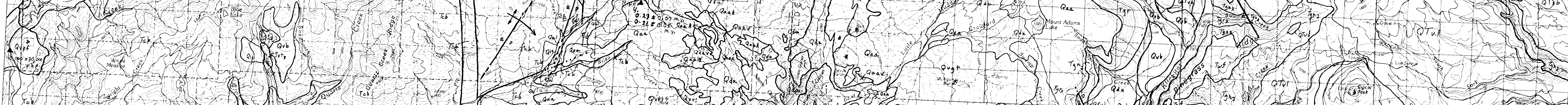

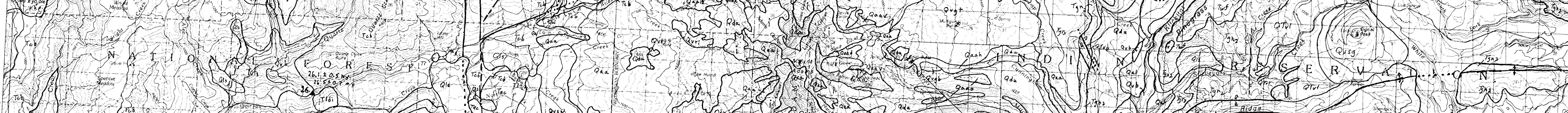
1. (2)

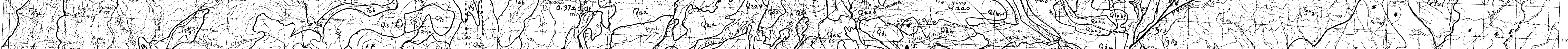

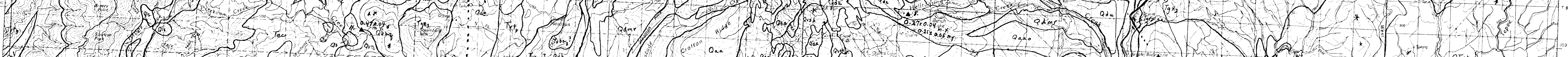

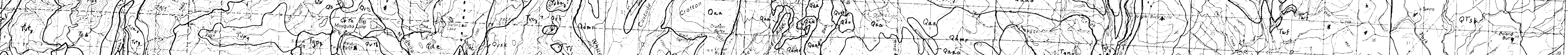

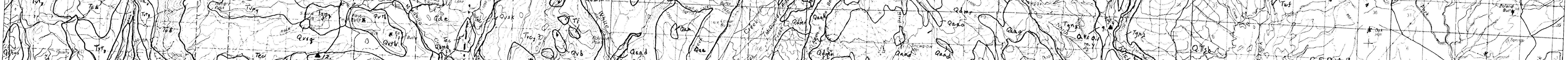

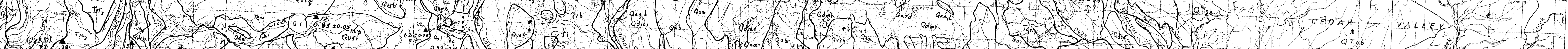

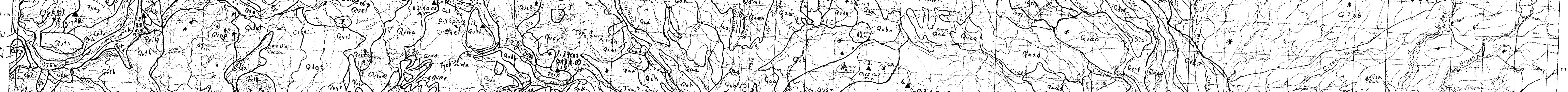

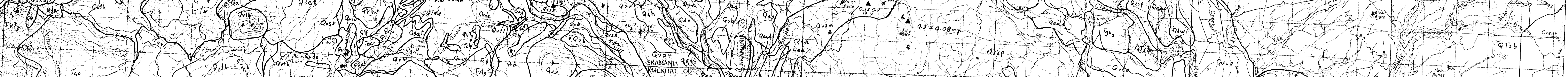

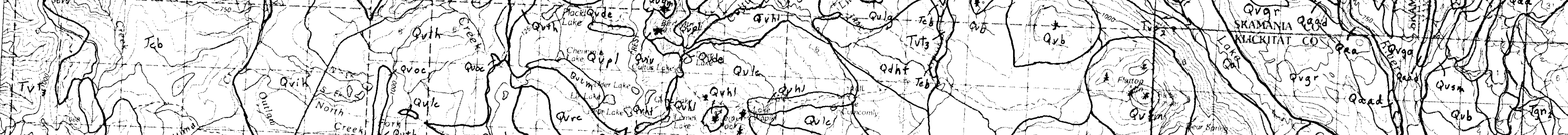

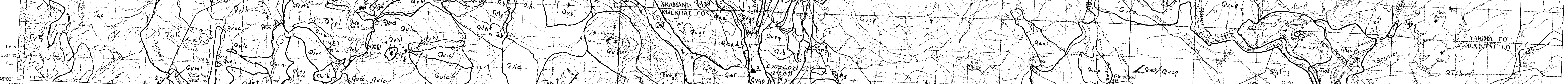
Dan
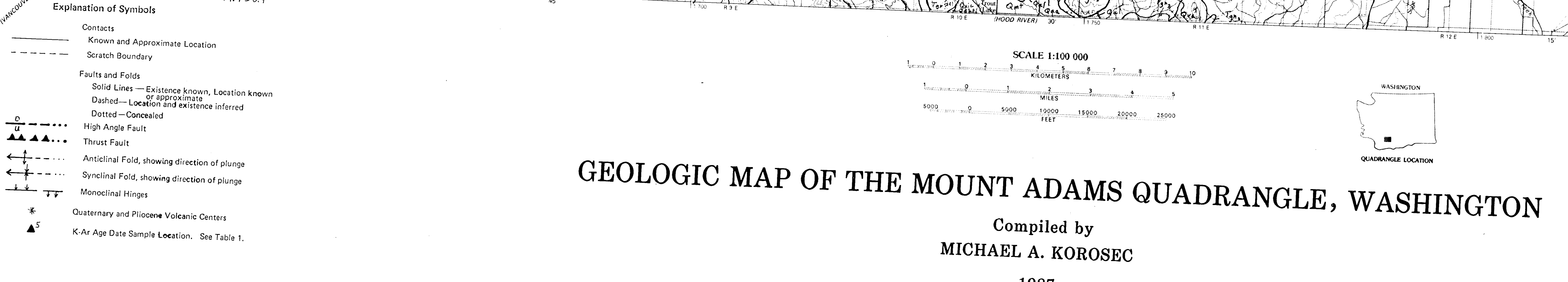
(n) 1.t. 